\title{
Stellaria ruderalis, a new species in the Stellaria media group from central Europe
}

\author{
Stellaria ruderalis, nový druh z okruhu Stellaria media ze střední Evropy
}

\author{
Martin Lepší ${ }^{1,2}$, Petr Lepší ${ }^{3}$, Petr Koutecký ${ }^{2}$, Magdalena Lučanováa,4, Eva Koutecká ${ }^{2}$ \\ \& Zdeněk Kaplan ${ }^{4,5}$
}

${ }^{1}$ South Bohemian Museum in České Budějovice, Dukelská 1, CZ-370 51 České Budějovice, Czech Republic, e-mail: lepsi@muzeumcb.cz; ${ }^{2}$ Department of Botany, Faculty of Science, University of South Bohemia, Branišovská 1760, CZ-370 05 České Budějovice, Czech Republic,e-mail: lepsi@seznam.cz,kouta@prf.jcu.cz,kubesovm@gmail.com, Eva.egi@seznam.cz; ${ }^{3}$ Nature Conservation Agency of the Czech Republic, Administration of the Blanský les Protected Landscape Area, Vyšný 59, CZ-381 01 Český Krumlov, Czech Republic, e-mail: plepsi@seznam.cz; ${ }^{4}$ The Czech Academy of Sciences, Institute of Botany, Zámek 1, CZ-252 43 Průhonice, Czech Republic, e-mail: kaplan@ibot.cas.cz; ${ }^{5}$ Department of Botany, Faculty of Science, Charles University, Benátská 2, CZ-128 01 Prague, Czech Republic

Lepší M., Lepší P., Koutecký P., Lučanová M., Koutecká E. \& Kaplan Z. (2019) Stellaria ruderalis, a new species in the Stellaria media group from central Europe. - Preslia 91: 391-420

\begin{abstract}
A new allotetraploid species in the Stellaria media group, S. ruderalis M. Lepší, P. Lepší, Z. Kaplan \& P. Koutecký, which is possibly of hybridogenous origin between S. pallida and S. neglecta, is distinguished and described based on a biosystematic revision of the S. media group. A suite of biosystematic techniques, including molecular (internal transcribed spacer sequencing), karyological (chromosome counting, flow cytometry), multivariate morphometrics and phenological observations, was used to assess the variation in this species group and determine the taxonomic status of the species. All the methods employed produced similar results and supported the delimitation of four species within the Stellaria media group in central Europe: Stellaria ruderalis $(2 \mathrm{n}=4 \mathrm{x}=44)$, S. pallida $(2 \mathrm{n}=2 \mathrm{x}=22)$, S. neglecta $(2 \mathrm{n}=2 \mathrm{x}=22)$ and $S$. media s. str. $(2 \mathrm{n}=4 \mathrm{x}=40)$. Stellaria ruderalis is a winter annual growing mainly in disturbed ruderal open or semi-open communities. This species' broad ecological amplitude allows it to commonly co-occur with its three related species. It is probably a widespread species in southern and central Europe. It is currently spreading in the northern part of central Europe. Photographs of the type specimen and individuals of the new species in situ are presented. Scanning electron micrographs of seeds, microphotographs of seeds and mitotic chromosome spreads and a key for the identification of all four species are provided.
\end{abstract}

Ke y w ord s: Caryophyllaceae, flow cytometry, internal transcribed spacer (ITS) sequencing, karyology, multivariate morphometrics, Stellaria media agg., taxonomy

\section{Introduction}

The Stellaria media group comprises three currently recognized species: S. media (L.) Vill., S. pallida (Dumort.) Crép. and S. neglecta Weihe, which are native to Eurasia and North Africa; their distribution centre is in southern and central Europe (Chater \& Heywood 1964, Scholte 1978, Chen \& Rabeler 2001, Morton 2005, Marhold 2011), but they 
have been introduced elsewhere (van Kleunen et al. 2019). The group is distinguished by the following set of characters: upper leaves sessile, lower leaves distinctly petiolate, leaves and bracts ovate or elliptical with round bases, stems terete, usually with a single line of hairs along each internode, rarely with two lines or glabrous, or in S. neglecta subsp. cupaniana (Jord. et Fourr.) Nyman, hairy all around, bracts herbaceous, flowers in dichasia, petals small or absent, at most one third longer than sepals, bifid almost to the base, and by a base chromosome number of $\mathrm{x}=11$ (except for dysploid $S$. media, see below). Within the genus Stellaria, this species group is assigned to subsection Petiolares Fenzl of the section Eustellaria Fenzl (Peterson 1936, Miller \& West 2012) or to the subgenus Alsine (L.) Tzvelev (Belkin 2011). Some authors even place the $S$. media group in the separate genus Alsine L. (Löve \& Löve 1975); however, a molecular phylogeny does not support this classification (Greenberg \& Donoghue 2011).

The most widespread taxon in this group is the tetraploid $S$. media, which is considered native to Europe but has a worldwide secondary distribution. It is generally absent only from the most arctic regions and very dry areas, but in the tropics it is common only at high altitudes (Turkington et al. 1980). It is a noxious weed of crops and also a ruderal characterized by early maturity and a wide ecological tolerance. Its very variable morphology has led some authors to describe many taxa, which are, however, mainly based on characters that are strongly influenced by the environment, are not retained in cultivation and show continuous variation (Scholte 1978, Turkington et al. 1980). This species is characterized by flowers with petals as long as or shorter than the sepals, 3-5 (-10) stamens and seed with rounded to flat tubercles on the dorsal surface (Chater \& Heywood 1964, Whitehead \& Sinha 1967, Scholte 1978, Turkington et al. 1980, Miller \& West 2012). There are two cytotypes of $S$. media s. str. in Europe. The $2 n=40$ cytotype is widespread whereas the $2 \mathrm{n}=44$ cytotype is confined to the southern part of the continent (Scholte 1978). These two cytotypes differ somewhat in morphology; however, they are not considered morphologically distinct because of the occurrence of intermediates. Despite the fact that they often occur sympatrically, no spontaneous hybrids are reported (Scholte 1978). Hybrids can be produced artificially, but they are less fertile (Peterson 1936). Some morphotypes of the 44-chromosome cytotype even have characters of S. pallida and S. neglecta (Scholte 1978), which indicates that S. media deserves further biosystematic attention.

The diploid $(2 \mathrm{n}=22) \mathrm{S}$. pallida is mainly a European taxon, with a distribution centre in southern Europe, extending eastwards to Anatolia and central Asia. It occurs secondarily in northern Europe, China, the Americas and Australia (Chen \& Rabeler 2001, Miller \& West 2012). It grows in open or semi-open sandy places such as established dunes or open pine forests. It is also a weed of cultivated plants and a ruderal (Whitehead \& Sinha 1967, Dvořáková 1990, Chen \& Rabeler 2001). From the rest of the group it is distinguished by 1-3 (-4) stamens, small, up to $1 \mathrm{~mm}$ long and light-brown seeds and absent or minute petals (Chater \& Heywood 1964, Whitehead \& Sinha 1967, Scholte 1978, Miller \& West 2012).

Stellaria neglecta $(2 \mathrm{n}=22)$ mainly inhabits riparian woods and scrubs, stream sides and wood margins and other semi-shaded places (Whitehead \& Sinha 1967, Scholte 1978, Dvořáková 1990). Its distribution extends from Europe to the Russian Far East and as an alien it is currently spreading in North America (Jalas \& Suominen 1983, Morton 2005, Belkin 2011). The diagnostic characters of this taxon are 8-10 (-11) stamens, 
petals usually equalling or exceeding sepals and long conical tubercles on seeds (Chater \& Heywood 1964, Whitehead \& Sinha 1967, Scholte 1978). In addition to the widespread diploid $S$. neglecta, there are also rare records of tetraploids $(2 n=44)$ from Italy. However the relationship of these two cytotypes is unclear (Peterson 1936, Scholte 1978). Further, S. neglecta subsp. cupaniana (diploid, $2 \mathrm{n}=22$, Runemark in Kamari et al. 1996) is a Mediterranean taxon, which differs from the type subspecies in having hairy stems and inflorescences (Chater \& Heywood 1964, Scholte 1978, Marhold 2011). Sometimes it is ranked as a subspecies of $S$. media and its classification requires further taxonomic study (Scholte 1978).

All the aforesaid species are very variable and it is difficult to find any clear-cut morphological distinction between them, though they can usually be distinguished when all relevant characters are considered together (Whitehead \& Sinha 1967). This and their distinct cytology are the reasons why these taxa have usually been treated as separate species, particularly recently (Chen \& Rabeler 2001, Morton 2005, Belkin 2011, Marhold 2011, Miller \& West 2012). Differences in their biology also support their separation: $S$. pallida is an autogamous and sometimes cleistogamous summer annual or winter annual, $S$. media is both an autogamous and occasionally cross-pollinated summer or winter annual and $S$. neglecta is usually a cross-pollinated but self-compatible winter annual or biennial (Peterson 1936, Dvořáková 1990, Morton 2005). Finally, there is no evidence of gene flow between the species (Chater \& Heywood 1964). However, Scholte (1978) reports many intermediate forms between S. media and the tetraploid S. neglecta in the Mediterranean area and concludes that these taxa are not distinct in this region and seem to be in an active stage of evolution. This stands in contrast with the situation in north-western Europe, where the taxa are clearly different (Scholte 1978).

In the Czech Republic, all three species are recognized (Dvořáková 1990, Danihelka et al. 2012). Although $S$. media is ubiquitous in this country, the remaining taxa have more limited distributions: $S$. neglecta is confined to hilly areas and lowlands in central and north-western Bohemia and S. pallida occurs mainly in eastern and central Bohemia and southern Moravia (Dvořáková 1990, Fajmon 2007). Stellaria pallida recently started to spread into areas where it had never been recorded. A similar trend is reported for S. neglecta in southern Bohemia (Boublík \& Petřík 2013). However, these plants differ morphologically from $S$. neglecta occurring in central Bohemia, which stimulated us to study the $S$. media group in the Czech Republic. Here we present a biosystematic revision of the $S$. media group and describe a new species, S. ruderalis.

\section{Material and methods}

\section{Plant material and field work}

Samples for morphometric and molecular analyses, flow cytometry, karyology, a garden experiment and herbarium specimens were collected in May 2017. Flowers were stored in $70 \%$ ethanol. Numbers of individuals sampled per species are summarized in Table 1 and details of the localities in Appendix 1. Herbarium specimens are deposited in the herbarium of the South Bohemian Museum in České Budějovice (CB; Thiers 2019). 
Table 1. - Number of individuals sampled per species in all of the biosystematic analyses and results of flow cytometry analyses of all species in the Stellaria media group delimited in this study. Bellis perennis L. was used as the internal standard and DAPI as the stain.

\begin{tabular}{lcccc}
\hline Taxon & S. pallida & S. neglecta & S. media & S. ruderalis \\
\hline Number of individuals analysed & 11 & 12 & 11 & 17 \\
Average sample/standard ratio & 0.303 & 0.369 & 0.624 & 0.648 \\
Standard error of mean & 0.001 & 0.001 & 0.001 & 0.001 \\
Minimum of sample/standard ratio & 0.297 & 0.363 & 0.619 & 0.639 \\
Maximum of sample/standard ratio & 0.308 & 0.376 & 0.627 & 0.660 \\
Estimated DNA ploidy level & $2 \mathrm{n} \sim 2 \mathrm{x}$ & $2 \mathrm{n} \sim 2 \mathrm{x}$ & $2 \mathrm{n} \sim 4 \mathrm{x}$ & $2 \mathrm{n} \sim 4 \mathrm{x}$ \\
\hline
\end{tabular}

\section{Flow cytometry}

DAPI flow cytometry was used to assess the DNA ploidy levels of 51 individuals, following the simplified two-step procedure of Doležel et al. (2007). About $0.25 \mathrm{~cm}^{2}$ of leaf tissue of each individual was chopped together with an appropriate amount of the internal standard (Bellis perennis leaf tissue; $2 \mathrm{C}=3.38 \mathrm{pg}$, Schönswetter et al. 2007) using a sharp razor blade in a Petri dish containing $0.4 \mathrm{ml}$ of ice-cold Otto I buffer $(0.1 \mathrm{M}$ citric acid, $0.5 \%$ Tween 20). The suspension was filtered through a $42-\mu$ m nylon mesh and incubated for 5-10 min at room temperature. After this incubation, isolated nuclei were stained with $0.8 \mathrm{ml}$ of Otto II buffer $\left(0.4 \mathrm{M} \mathrm{Na}_{2} \mathrm{HPO}_{4} .12 \mathrm{H}_{2} \mathrm{O}\right)$ supplemented with 2-mercaptoethanol (2 $\mu \mathrm{g} / \mathrm{ml}$ ) and 4',6-diamidino-2-phenylindole (DAPI) (4 $\mu \mathrm{g} / \mathrm{ml})$. Samples were run through a Partec PA II flow cytometer (Partec GmbH, Münster, Germany, now Sysmex) equipped with a mercury arc lamp as the UV light excitation source. The fluorescence intensity of 3000 particles was recorded. Fluorescence histograms were evaluated using FloMax 2.6 software provided by the cytometer manufacturer. Individual standard-to-sample ratios are given in Appendix 1.

\section{Karyology}

Chromosome counts were determined using root tips of germinating seedlings. Seeds originated from individuals ID 87, 112 (S. media), ID 120, 132 (S. neglecta), ID 99, 105 (S. pallida), ID 81 (S. ruderalis). See Appendix 1 for details of the localities. Seedlings were pretreated for four hours in p-dichlorobenzene and then fixed in freshly prepared Carnoy's fixative (ethanol : acetic acid $3: 1$ ) for $15 \mathrm{~min}$ at room temperature and stored at $-20^{\circ} \mathrm{C}$ until required.

For chromosome preparation a modified protocol of Mandáková \& Lysak (2016) was applied. The seedlings were washed in distilled water twice for $5 \mathrm{~min}$, then in $1 \times$ citrate buffer twice for $5 \mathrm{~min}$ and then the buffer was replaced with an enzymatic mixture $(0.3 \%$ pectolyase, $0.3 \%$ cellulase, $0.3 \%$ cytohelicase in citrate buffer). After 90 min digestion at $37{ }^{\circ} \mathrm{C}$, the enzymatic mix was replaced with $1 \times$ citrate buffer and the temperature of the material reduced to $4{ }^{\circ} \mathrm{C}$ for $15 \mathrm{~min}$. Afterwards, each seedling was placed on a slide, the meristematic part of root tip was separated and the rest of the seedling was discarded. The meristem was tapped with a preparation needle until a suspension formed. Then, $20 \mu \mathrm{l}$ of $60 \%$ acetic acid were added to the suspension, the slide was placed on a heating block at $50{ }^{\circ} \mathrm{C}$ and the suspension spread with a preparation needle for $30 \mathrm{~s}$. Afterwards, $100 \mu \mathrm{l}$ of freshly prepared Carnoy's fixative was added in order to fix the chromosomes, the liquid 
Table 2. - Polymorphic positions in the alignment of ITS sequences of the Stellaria media group obtained by direct sequencing. The sequence of sample ID 99 is used as a reference and identical nucleotides in other sequences are displayed as dots. Sites with nucleotide polymorphisms are coded using IUPAC codes. GenBank accession numbers for each sequence are provided.

\begin{tabular}{|c|c|c|c|c|c|c|c|c|c|c|c|c|c|c|c|c|c|c|c|}
\hline \multirow{2}{*}{$\frac{\text { Taxon, sample ID }}{\text { S. pallida }}$} & \multirow[t]{2}{*}{ GenBank } & \multicolumn{18}{|c|}{ 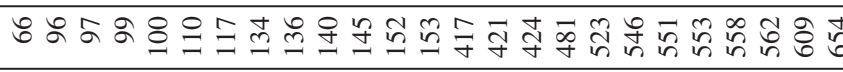 } \\
\hline & & & & & & & & & & & & & & & & & & & \\
\hline 99 & MN180160 & A & $\mathrm{AC}$ & $\mathrm{C}$ & & & $\mathrm{C} \mathrm{C}$ & & $\mathrm{C}$ & & & & $\mathrm{T}$ & $\mathrm{T} \mathrm{G}$ & $\mathrm{T} \mathrm{C}$ & & G Y R & $\mathrm{R} \mathrm{C}$ & $\mathrm{C}$ \\
\hline $86,95,98,101,103,105,106,133 b$ & MN180161 & & & & & $\mathrm{Y}$ & & 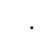 & 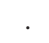 & & & . & & & . $\mathrm{F}$ & $\mathrm{R}$ & $\mathrm{C}$. & $\mathrm{Y}$ & \\
\hline 92 & MN180162 & . & & & & $\mathrm{T}$ & & 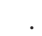 & 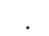 & & & 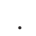 & & & & $\mathrm{R}$. & . . . & . . & \\
\hline 93 & MN180163 & & . & & & . & . . & & 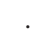 & . & & . & & & & $\mathrm{R}$. & . . . & . & \\
\hline \multicolumn{20}{|l|}{ S. ruderalis } \\
\hline 130 & MN180164 & & . & . & & . & . & $\mathrm{Y}$ & & & . W & . & & & . & . & G & G & \\
\hline 77 & MN180165 & . & . & . & & & . & Y & 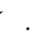 & . & . $\mathrm{W}$ & & $\mathrm{Y}$ & Y & . & . . & . $\mathrm{C} \mathrm{G}$ & G & \\
\hline 88 & MN180166 & . & . & . & & B & . & $\mathrm{Y}$ & 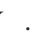 & . & & . & Y & Y & . & . . & . . G & G Y & \\
\hline 74 & MN18 & . & . & & & $\mathrm{S}$ & . & . & . & . & . W & . & Y & Y & . & . $\mathrm{R}$ & R. G & G Y & \\
\hline 79,81 & MN180168 & . & . & . I & $y$ & B & 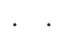 & Y & . & 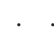 & . & . & Y & Y & . & . $\mathrm{R}$ & $R \cdot G$ & G Y & \\
\hline $85,133 \mathrm{a}$ & MN18 & & & .1 & & B & - & Y & . & . & . & . & Y & Y & . & . $\mathrm{R}$ & $\mathrm{R}$ & G Y & \\
\hline 100,104 & MN180170 & & & . & Y & $\mathrm{B}$ & . & Y & r & . & & . & $\mathrm{Y}$ & Y & $\mathrm{Y}$ & . . & $\mathrm{R} \cdot \mathrm{G}$ & G Y & \\
\hline $75,89,107$ & MN180171 & & & . 1 & I & B & & Y & & & . W & . & $\mathrm{Y}$ & Y & . & . & R. G & G Y & \\
\hline 114 & MN1 & & & . 1 & $Y$ & B & & $\mathrm{Y}$ & & & . W & . & Y & Y & $\mathrm{Y}$ & & R. G & G Y & \\
\hline 121 & MN18 & & & . & Y & $\mathrm{S}$ & & Y & & & . & . & $\mathrm{Y}$ & Y & $\mathrm{Y}$ & . $\mathrm{R}$ & $\mathrm{R} \mathrm{C} \mathrm{G}$ & $\mathrm{G}$ & \\
\hline 97 & MN180174 & $\mathrm{R}$ & $R$ & & & $\mathrm{~V} B$ & $\mathrm{Y}$ & 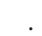 & $\mathrm{Y}$ & & $\mathrm{K}$ & . & Y & Y & . & . . & . . G & G & $\mathrm{Y}$ \\
\hline \multicolumn{20}{|l|}{ S. neglecta } \\
\hline 131 & MN180175 & . & & . 1 & $\Gamma$. & G & & $\mathrm{T}$ & & & & . & & & $\mathrm{C}$ & . . & $\mathrm{A} \mathrm{C} \mathrm{G}$ & & \\
\hline $126,127,132$ & MN180176 & . & . & .7 & $\Gamma$. & G & . & $\mathrm{T}$ & 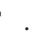 & Y & & 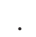 & & $\mathrm{C}$ & $\mathrm{C}$ & . . & A C G & G & . \\
\hline 135 & MN1 & & . & .7 & . & G & & $\mathrm{T}$ & . & Y & & 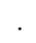 & & $\mathrm{C}$ & $\mathrm{C}$ & . . & $\mathrm{M} \mathrm{C} \mathrm{G}$ & & . \\
\hline \multirow{2}{*}{\multicolumn{20}{|c|}{ S. media }} \\
\hline & & & & & & & & & & & & & & & & & & & \\
\hline 76 & MN180179 & & & .7 & & G & & $\mathrm{T}$ & & Y & & . & & $\mathrm{C} \mathrm{K}$ & $\mathrm{C}$ & . & A C G & & \\
\hline $78,87,111$ & MN180180 & $\mathrm{R}$ & $\mathrm{R}$ & Y Y & & $\mathrm{G}$ & & $\mathrm{Y}$ & $\mathrm{Y}$ & & $\mathrm{K}$ & . & & $\mathrm{C}$ & Y & . & $\mathrm{R} \mathrm{C} \mathrm{G}$ & G & Y \\
\hline 94 & MN180181 & $\mathrm{R}$ & R & Y Y & & $\mathrm{G}$ & $\mathrm{Y}$ & $\mathrm{Y}$ & $\mathrm{Y}$ & & K & $\mathrm{Y}$ & & $\mathrm{C}$ & $\mathrm{Y}$ & 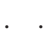 & $\mathrm{R} \mathrm{C} \mathrm{G}$ & G & $\mathrm{T}$ \\
\hline 115 & MN180182 & & $\mathrm{R}$ & Y Y & & $\mathrm{G}$ & & & $Y$ & & K & 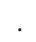 & & $\mathrm{C}$ & $\mathrm{Y}$ & . & $\mathrm{R} \mathrm{C} \mathrm{G}$ & G & $\mathrm{Y}$ \\
\hline 90,102 & MN180183 & & $\mathrm{R}$ & & & G & $\mathrm{T}$ & & $\mathrm{Y}$ & & $\mathrm{T}$ & 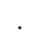 & & $\mathrm{C}$ & & . & G C G & & $\mathrm{T}$ \\
\hline 123,128 & MN180184 & & $\mathrm{G}$ & & & G & & & $\mathrm{T}$ & & $\mathrm{T}$ & 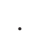 & & $\mathrm{C}$ & . & . . & G C G & & $\mathrm{T}$ \\
\hline 112 & MN180185 & & $\mathrm{G}$ & & & G & $\mathrm{T}$ & & $\mathrm{T}$ & & $\mathrm{T}$ & $\mathrm{Y}$ & & C & . & . . & $\mathrm{GC} \mathrm{G}$ & G & $\mathrm{T}$ \\
\hline
\end{tabular}

was drained by tilting the slide and the dry slide was placed in a box kept at $4{ }^{\circ} \mathrm{C}$. Lastly, $15 \mu \mathrm{l}$ of Vectashield with DAPI were added as a staining solution and the preparation was covered with a cover slip and fixed with nail polish. Chromosomes were observed under a Nikon Eclipse E600 fluorescence microscope equipped with a Nikon DS-Qi1Mc camera and images were obtained using NIS-Elements AR software. For every chromosome count, at least five sets of chromosomes at the metaphase stage of mitosis were observed.

\section{Molecular analyses}

To gain an insight into the differences between the individual taxa, we performed a pilot study using the internal transcribed spacer (ITS) region of nuclear ribosomal DNA. Total genomic DNA was extracted from silica-dried leaves of 49 individuals (see Table 2 and Appendix 1 for locality details) following the CTAB-protocol (Doyle \& Doyle 1987) with minor modifications. The ITS region was amplified using the ITS-F forward primer 
(King et al. 2001) and the ITS4 reverse primer (White et al. 1990). Each PCR was run in $7.5 \mu \mathrm{l}$ reactions containing $3.75 \mu \mathrm{l}$ of Plain PP Master Mix (Top-Bio, Czech Republic), $0.45 \mu \mathrm{l}$ of each primer (concentration $5 \mu \mathrm{M}$ ), $1.85 \mu \mathrm{l}$ of $\mathrm{H}_{2} \mathrm{O}$ and $1 \mu \mathrm{l}$ of the sample DNA. The cycling program was: $94^{\circ} \mathrm{C}$ for $5 \mathrm{~min} ; 35$ cycles of $94{ }^{\circ} \mathrm{C}$ for $30 \mathrm{~s}, 53{ }^{\circ} \mathrm{C}$ for $30 \mathrm{~s}$ and $72{ }^{\circ} \mathrm{C}$ for $1 \mathrm{~min}$, with final elongation at $72{ }^{\circ} \mathrm{C}$ for $10 \mathrm{~min}$. Successful amplifications were purified with Escherichia coli Exonuclease I and FastAP (Thermosensitive Alkaline Phosphatase; Fermentas, Germany) following the manufacturer's instructions and sequenced using the ITS4 primer by a commercial company (GATC Biotech, Germany). Selected samples of all taxa were sequenced also from the opposite direction using the ITS-F primer to confirm the polymorphisms, and consensus sequences were used. Raw sequence data were inspected using Finch TV 1.4 software (Geospiza, USA); positions showing multiple peaks (with the lower peak at least one-fourth of the height of the higher peak) were coded using standard IUPAC ambiguity codes. The resulting sequences were aligned manually using BioEdit 7.2.0 (Hall 1999). The sequence data are deposited in the GenBank database; see Table 2 for accession numbers.

As most of the variable sites contained ambiguous bases and because an additive pattern was visible in many samples, the sequence data were visualized as a network using SplitsTree 4.14.8 software (Huson \& Bryant 2006). We applied a Neighbour Net algorithm based on uncorrected $\mathrm{P}$ distance; the handling of ambiguous states was set to average (however, we also tested the "match states" option, which resulted in a network with a similar structure).

\section{Morphometric analyses}

Multivariate morphometric analyses were used to reveal species-specific characters of the newly recognized species and how differs from those of the three related and cooccurring taxa in the S. media group: S. media, S. neglecta and S. pallida. A set of 12 quantitative characters was chosen based our observations, identification keys, floras and taxonomic studies (e.g. Chater \& Heywood 1964, Whitehead \& Sinha 1967, Scholte 1978, Dvořáková 1990, Fischer 2008, Stace 2010). The characters are listed in Table 3. Characters were measured using a ruler or a stereo microscope (total magnification range $6.3 \times-57 \times)$. Three measurements of each character per individual were recorded and their arithmetic mean was used as the value for the given individual in all morphometric analyses. Each individual consists of several stems, allowing multiple measurements of each predefined character. Flowers and fruits were sampled at the beginning of the fruiting period of each individual. Pearson correlation coefficients were calculated for pairs of characters of each species and for the whole dataset. Principal component analysis (PCA) was used to provide an insight into the overall pattern of morphological variation and reveal potential separation of the species analysed. Prior to the PCA, the data were logtransformed and standardized to zero mean and unit standard deviation. Linear discrimination analysis (LDA), which maximizes differences between a priori defined groups (based on genome size data), was used to test the discriminating power of morphometric characters, following the methodology described by Lepš \& Šmilauer (2003). Forward selection of characters using non-parametric Monte Carlo permutation tests ( 999 permutations) was employed. The PCA and LDA were carried out using CANOCO 4.5 software (Lepš \& Šmilauer 2003). A cross-validated classificatory linear discriminant analysis 


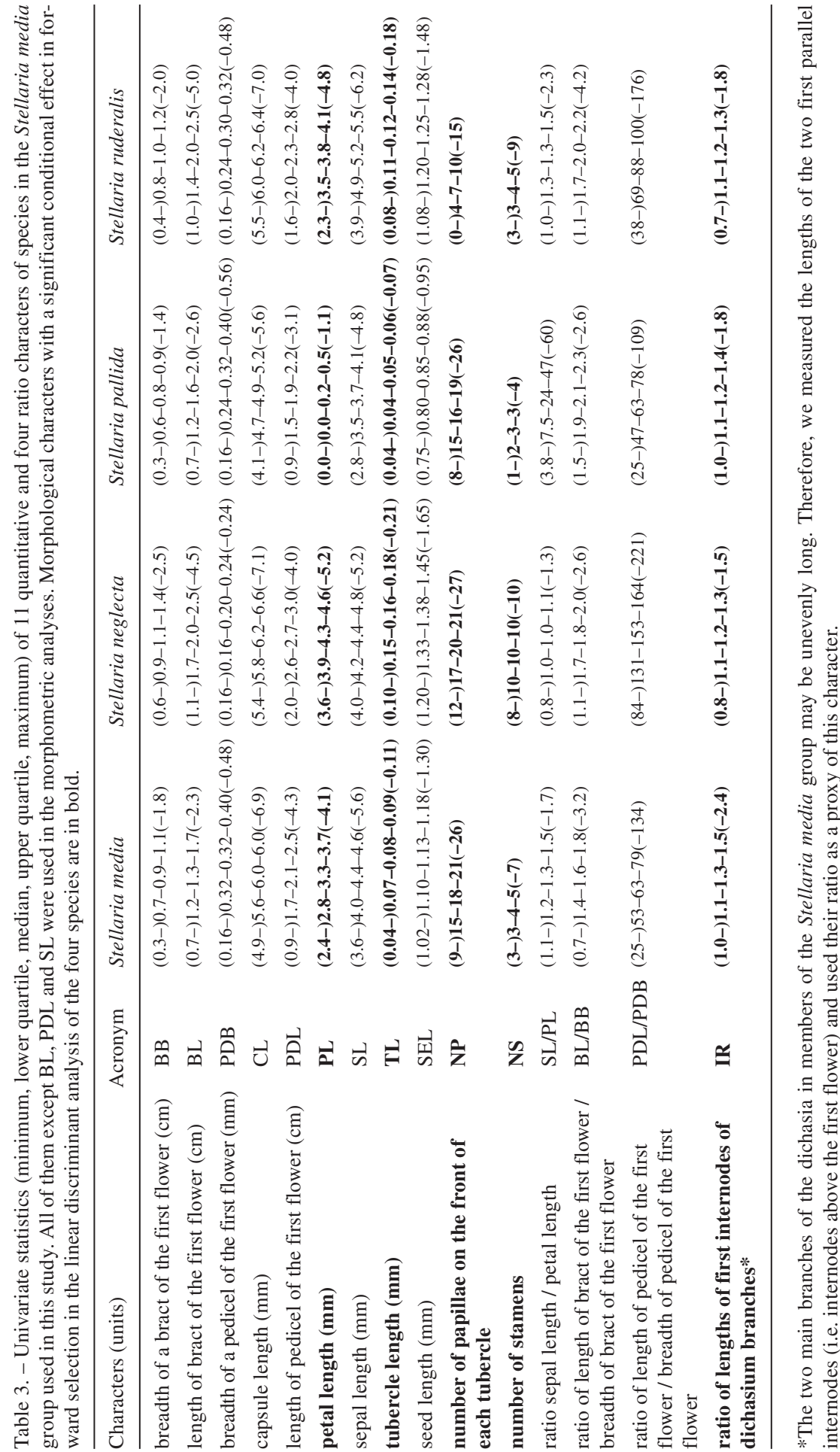


based on probabilities using only characters selected by the previous analysis was performed in R version 2.12.2 (R Development Core Team 2011) using the "lda" function in the MASS package (Venables \& Ripley 2002). Univariate statistics (minimum, maximum, median, quartiles) of quantitative characters of all individuals were calculated and used in the description of the species. They are summarized in Table 3 for all the species studied.

\section{Seed germination and life cycle}

This experiment was carried out in České Budějovice at L. B. Schneidera street 6 $\left(48^{\circ} 57^{\prime} 42.6^{\prime \prime} \mathrm{N}, 1^{\circ} 28^{\prime} 16.3^{\prime \prime} \mathrm{E}\right.$, WGS84). Ten seeds from each of 51 individuals were sown in flower pots on 12 June 2017 (seeds of one individual per pot). Sterile potting soil composed of peat and bark compost was used. The pots were placed in sand to prevent them from rapidly drying out. They were also protected from direct sunlight by shade netting and against heavy rain by transparent plastic foil. The plants were regularly irrigated during the experiment. Most of the seeds in a pot germinated within three days of the emergence of the first seedling. The date of emergence of the first seedling was recorded and used in the results presented below. Germination was monitored every day for 77 days; the plants were then cultivated until April 2018.

\section{Results and discussion}

Our field observations, detailed investigations of herbarium material, results of flow cytometry, karyology, molecular analyses, morphometric analyses and observations on phenology are congruent with each other and support the delimitation of four species within the Stellaria media group in central Europe. Three of them correspond to S. pallida, S. neglecta and S. media s. str., and the fourth is described below as a new species under the name $S$. ruderalis.

\section{Ploidy level}

Flow cytometry yielded high-resolution histograms with coefficients of variation of both the sample and the standard peak mostly below $2 \%$. Four distinct groups with non-overlapping relative genome sizes were revealed, two putatively diploid and two putatively tetraploid (Table 1). The detected ploidy levels of the three previously recognized species correspond to the reported chromosome numbers (e.g. Chater \& Heywood 1964).

\section{Karyology}

We confirmed the chromosome number of $2 n=22$ for both of the diploid species S. neglecta and S. pallida (Fig. 1A, B). For both species these findings are the first records from the Czech Republic and are congruent with most of the records of their karyology from Europe (Rice et al. 2015). In tetraploids we found the relative genome size differed for different chromosome numbers. We detected 40 chromosomes in Stellaria media ( $2 \mathrm{n}=4 \mathrm{x}=40$; Fig. 1C), which is in line with the only record from the Czech Republic from southern Moravia (Měsíček \& Jarolímová 1992) and with published counts from many other countries all over the world (Scholte 1978 and references therein). Stellaria 


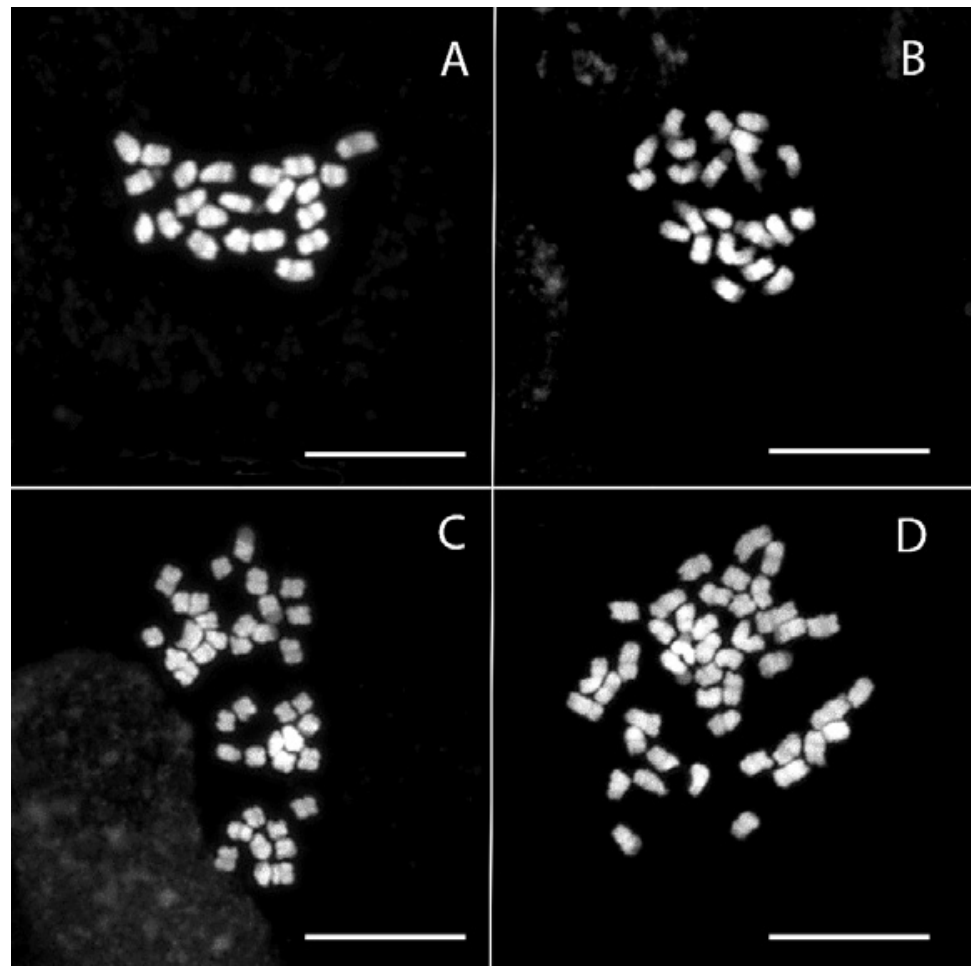

Fig. 1. - DAPI-stained mitotic chromosome spreads from roots of plants in the Stellaria media group. A - S. neglecta ID $132(2 \mathrm{n}=2 \mathrm{x}=22), \mathrm{B}-$ S. pallida ID $105(2 \mathrm{n}=2 \mathrm{x}=22), C-$ S. media ID $112(2 \mathrm{n}=4 \mathrm{x}=40)$, $\mathrm{D}-\mathrm{S}$. ruderalis ID $81(2 \mathrm{n}=4 \mathrm{x}=44)$. See Appendix 1 for details of the localities. Scale bars $=10 \mu \mathrm{m}$.

ruderalis is also tetraploid but has 44 chromosomes in somatic cells $(2 n=4 x=44$; Fig. 1D). This chromosome number is reported for Stellaria media s.l. in a few mostly south-European countries, Georgia and Iran (Peterson 1936, Scholte 1978, Keshavarzi \& Esfandani Bozchaloyi 2014, Rice et al. 2015).

\section{Molecular analyses}

The alignment of the ITS region was 709 bp long and contained only substitutions; no variation in length was recorded. In total, 24 sites were polymorphic in at least two samples and one additional unique polymorphism occurred (Table 2). The phylogenetic network (Fig. 2) shows that diploid taxa S. neglecta and S. pallida are clearly different and relatively homogeneous. The little infra-specific variation is associated with a few sites that in some samples display intra-individual polymorphisms, with one of the contributing bases being the same as in the "pure" variants.

In the tetraploid $S$. media, three main sequence types can be recognized. Five samples had a very distinctive sequence that is specific to this species. In the other five samples this specific sequence was combined with that of $S$. neglecta in an additive manner. One sample (ID 76) had a sequence identical with one of the $S$. neglecta variants. The ITS 


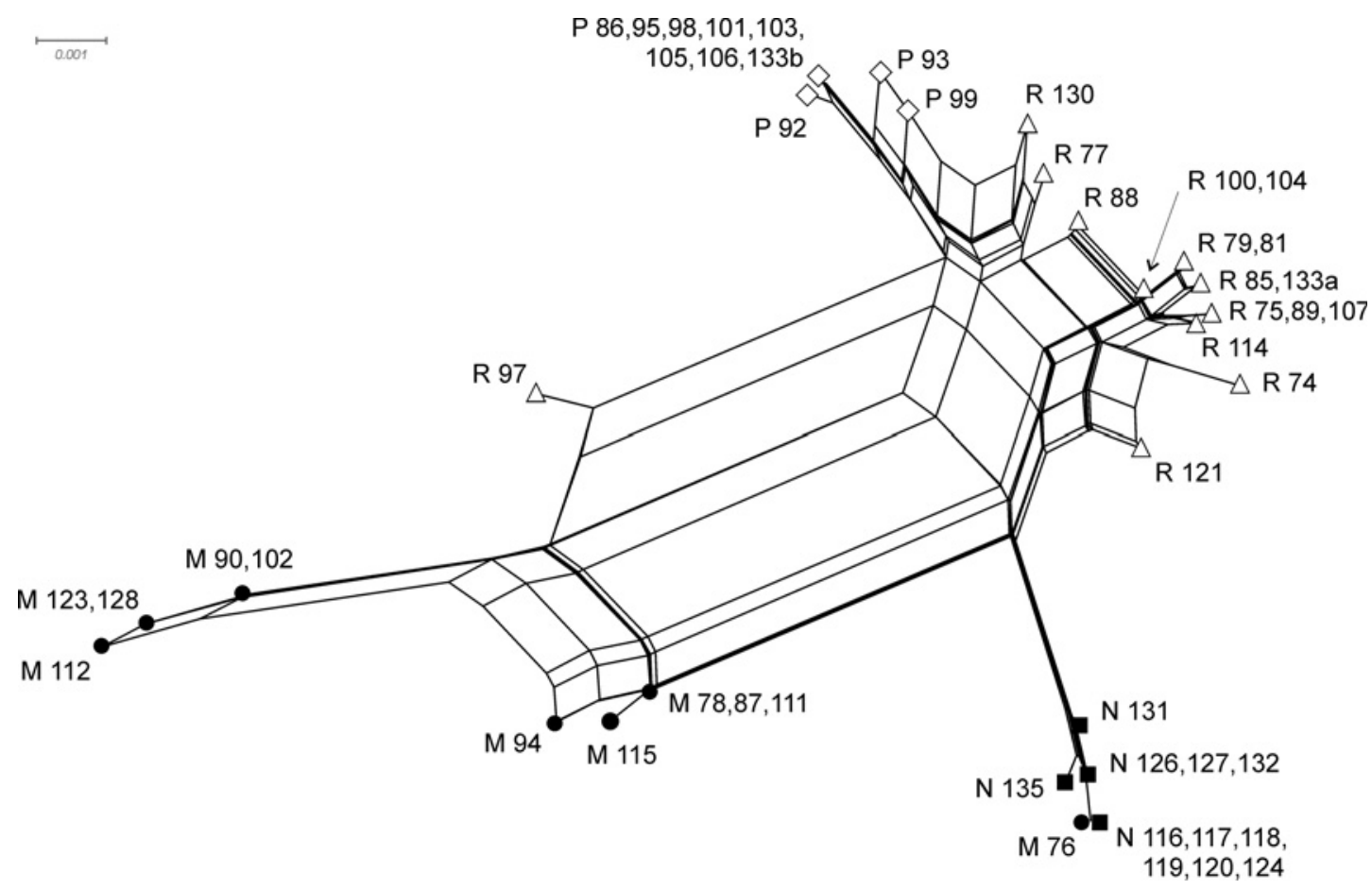

Fig. 2. - NeighbourNet diagram of ITS sequences of the Stellaria media group in central Europe. Symbols for taxa are identical to those used in the morphometric analyses. Sample identifiers follow Appendix 1 and are preceded by taxon abbreviations $(\mathrm{M}-\mathrm{S}$. media, $\mathrm{N}-$ S. neglecta, $\mathrm{P}-\mathrm{S}$. pallida, $\mathrm{R}-\mathrm{S}$. ruderalis $)$.

region has been subject to concerted evolution during which the repetitive DNA sequences were homogenized, resulting in different parental copies prevailing in different individuals, but this process may be incomplete in evolutionary young taxa (e.g. Koch et al. 2003). Such a process may account for the pattern recorded in our dataset. Most likely, S. media is an allotetraploid, with one parent being $S$. neglecta. The other parent, contributing the $S$. media-specific sequences, was not sampled and could be an unknown genotype or even unrecognized taxon originating from southern Europe or adjacent western Asia. Indeed, Scholte (1978) postulates that S. media arose from a S. neglecta-like ancestor, although the exact origin suggested by him is different: he assumes either an autotetraploid origin from $S$. neglecta or, less probably, an allopolyploidy of the hybrid between $S$. neglecta and $S$. pallida. The allopolyploid $S$. media either underwent a chromosome number change leading to $\mathrm{x}=10$ or it originates from the hybridization of a taxon in which $\mathrm{x}=11$ ( $S$. neglecta-like) and one in which $\mathrm{x}=9$, but we consider the later unlikely as this chromosome number is not recorded in any of the related Stellaria taxa.

The last taxon, $S$. ruderalis, is the most variable of the four taxa studied. The ITS region of some individuals is similar to that of $S$. pallida, but others additively combine $S$. pallida and $S$. neglecta-like variants. However, the latter always exhibits a few $S$. ruderalis-specific sites. Therefore, $S$. ruderalis might be an allopolyploid between $S$. pallida and a taxon or genotype close to but not identical with the central-European 
S. neglecta. One individual (ID 97) contained the $S$. media-specific ribotype combined additively with that of $S$. ruderalis; in this individual we cannot exclude some role of hybridization at the tetraploid level, although this individual did not differ in genome size or morphology from most populations of S. ruderalis.

In summary, our preliminary data confirm the separate status of $S$. ruderalis among central-European taxa. Our pilot study also revealed considerable intra-specific variation in the ITS region. To elucidate the origins of all the taxa (both tetraploids are likely to be allopolyploid) and their phylogenetic relationships, other molecular markers are needed. Chloroplast markers, for example, could indicate the direction of hybridization. Moreover, broader sampling throughout the distributions of all taxa is desirable, as some regional-scale differentiation might be present. For a proper phylogenetic analysis of the ITS region, sampling more individuals is necessary to capture different variants that might be fixed by concerted evolution, especially in polyploids.

\section{Morphometric analyses}

No highly correlated characters $(r>10.95 \mid)$ were found, so all characters were used in the multivariate analyses. PCA showed a clear morphological differentiation between all the taxa studied (Fig. 3). The characters contributing the most to the first principal component (explaining $49.0 \%$ of the overall variation) were: seed length (SEL), petal length (PL), tubercle height (TL), number of stamens (NS), sepal length to petal length ratio (SL/PL). The first axis separates the diploids $S$. neglecta and S. pallida whereas the tetraploids $S$. media and $S$. ruderalis formed a distinct group in an intermediate position between the diploids. The second axis separates the tetraploids and diploids. The most tightly correlated characters with the second component axis (explaining 16.8\% of the overall variation) were the ratios of the lengths of first internodes of dichasium branches (IR), ratio of the lengths of the bract of the first flower to the breadth of the bract of the first flower (BL/BB) and length of the bract of the first flower (BL). The two tetraploids, $S$. media and S. ruderalis, were clearly separated along the third axis (Fig. 3). The third axis explained $10.9 \%$ of the overall variation and the most strongly correlated characters were: number of papillae on the front side of each tubercle (NP), BL/BB and NS.

A subsequent LDA also revealed that these four species are morphologically distinct. No overlap in the canonical scores was detected. Similar to the PCA, the first axis (explaining $32.2 \%$ of the overall variation) separates the diploids, whereas the tetraploids formed a distinct group between the diploids. The second axis (explaining 29.1\% of the overall variation) separates the tetraploids and diploids (Fig. 4). The most tightly correlated characters were number of papillae on the front of each tubercle (NP), number of stamens (NS) and petal length (PL). The separation of the two tetraploids was distinct along the third component axis (explaining $24.3 \%$ of the overall variation, Fig. 4). The most correlated characters were NP, ratio of lengths of first internodes of dichasium branches (IR) and tubercle height (TL). The forward selection procedure identified five characters with a significant conditional effect: PL, NS, NP, TL, IR; all characters had significant marginal effects (Table 4).

The classificatory discriminant analysis using these characters resulted in correct classification in all cases. The LDA of the two morphologically close tetraploids, S. media and $S$. ruderalis, revealed no overlap in the canonical scores for these species. The for- 

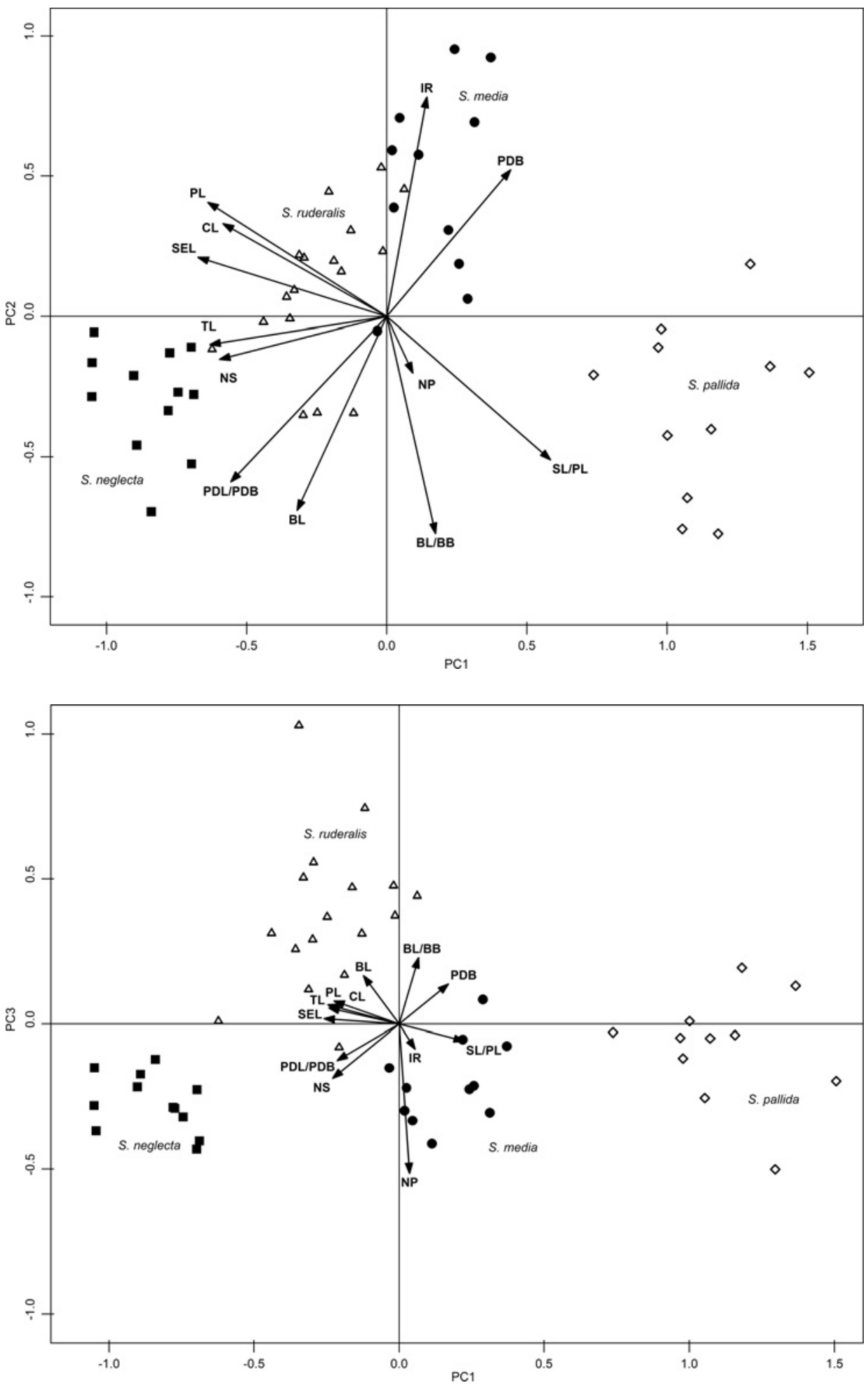

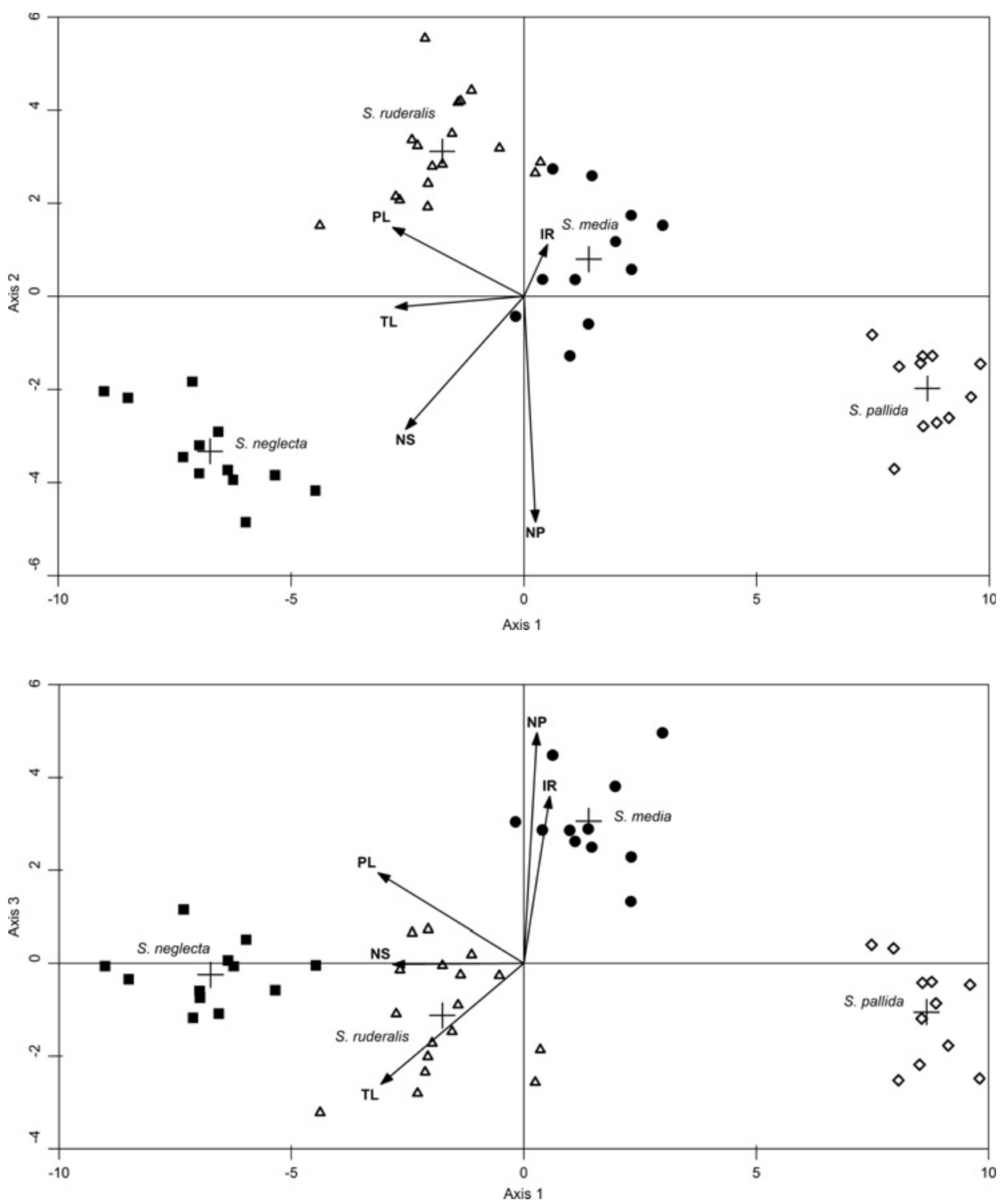

A Fig. 4. - Results of linear discriminant analysis based on five morphological characters of four species in the Stellaria media group. The characters were selected by a forward selection procedure. The first, second and third canonical axes are displayed, explaining $32.2 \%, 29.1 \%$ and $24.3 \%$ of the variation in the data, respectively. Discriminating characters, centroids of classes (crosses) and canonical scores of individual plants on the first, second and third discriminating axes are displayed. For abbreviations of character names, see Table 3.

Fig. 3. - Results of principal component analysis based on twelve morphological characters of the four species in the Stellaria media group studied. The first, second and third ordination axes are displayed. These explain $49.0 \%, 16.8 \%$ and $10.9 \%$ of the overall variation, respectively. For abbreviations of characters, see Table 3 . 
Table 4. - Morphological characters of species of the Stellaria media group with a significant conditional effect (i.e. the effect of the variable in addition to other variables already included in the model) in forward selection of two separate linear discriminant analyses: (i) characters of all cytotypes (diploid and tetraploid), (ii) characters of tetraploids (S. media and S. ruderalis). Arithmetic means of three measurements of each character per individual were used. Significance was tested using the Monte Carlo permutation test (999 permutations). $\lambda$ - eigenvalue, i.e. discriminant force of a particular character, $\mathrm{P}-\mathrm{P}$-value (conditional effect), marg. - characters with significant marginal effects (i.e. the effect of the variable when alone in the model). The contributions of characters to the ordination axes are depicted in Fig. 4. For abbreviations of characters, see Table 3.

\begin{tabular}{|c|c|c|c|c|c|}
\hline \multicolumn{3}{|c|}{ All species } & \multicolumn{3}{|c|}{ Tetraploids } \\
\hline Character & $\lambda$ & $\mathrm{P}$ & Character & $\lambda$ & $\mathrm{P}$ \\
\hline PL & 0.93 & 0.001 & NP & 0.81 & 0.001 \\
\hline NS & 0.84 & 0.001 & TL & 0.05 & 0.005 \\
\hline NP & 0.65 & 0.001 & PL & 0.03 & 0.009 \\
\hline $\mathrm{TL}$ & 0.1 & 0.001 & SL/PL & 0.03 & 0.009 \\
\hline IR & 0.04 & 0.019 & & & \\
\hline marg.: all & & & marg.: all & IR, & \\
\hline
\end{tabular}

ward selection procedure identified four characters (NP, TL, PL and SL/PL) with a significant conditional effects and eight characters with significant marginal effects (Table 4, BL, BL/BB, NP, PDB: breadth of the pedicel of the first flower, PDL/PDB: ratio of the length of pedicel of the first flower / breadth of pedicel of the first flower, PL, SEL, TL). The cross-validated discriminant analyses using these four and eight characters, respectively, resulted in correct classification in all cases.

The results of our morphometric analyses and field observations are in line with all major diagnostic characters used for the delimitation of the taxa in this group in taxonomic works and floras (Peterson 1936, Whitehead \& Sinha 1967, Scholte 1978, Morton 2005). However, we have not observed the differences between the species in the indumentum of sepals reported by Scholte (1978), and we also did not find any seeds of $S$. media s. str. that were smaller than $1 \mathrm{~mm}$, which contradicts the reported seed size of (0.8-) 0.9-1.3 (-1.4) mm (Chater \& Heywood 1964, Whitehead \& Sinha 1967, Scholte 1978, Turkington et al. 1980, Miller \& West 2012). Our sampling might not cover the entire range of variability in seed size; for example, $S$. media may produce smaller seeds under unfavourable condition on dry and nutrient-poor soils. In a similar manner, our dataset used in the morphometric analyses did not include any measurements of flowers of $S$. media and $S$. ruderalis with ten stamens, even though we observed these numbers several times in the field.

\section{Seed germination and life cycle}

The species studied differed significantly in terms of seed germination and flowering. Part of the sample for $S$. media and all of that for $S$. neglecta germinated after 7-15 and 9-22 days, respectively, whereas the seed of $S$. ruderalis, $S$. pallida and remaining seed of S. media started to germinate approximately 48-77 days after sowing (Fig. 5). All plants of $S$. media (except for one which was of aberrant appearance and did not flower) flowered and produced seeds in the year they were sown whereas the remaining three species bloomed the following year. All individuals of S. pallida and $80 \%$ of those of $S$. ruderalis 


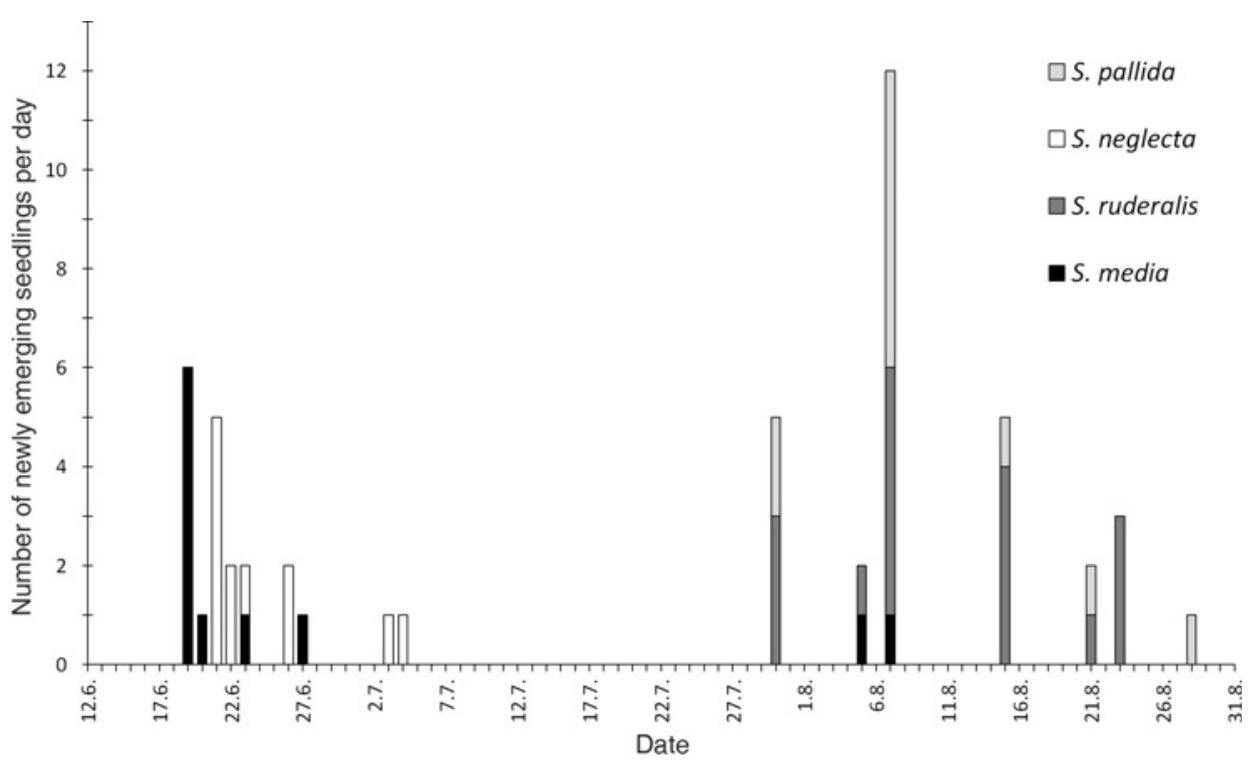

Fig. 5. - Results of a germination experiment on members of the Stellaria media group. Seeds from 51 plants (samples) of four species were sown in separate flower pots on 12 June 2017 and observed daily. Most seeds in a pot germinated within three days after the emergence of the first seedling, so the dates of the emergence of the first seedling in each pot are presented in the graph.

were in flower on 9 April 2018, whereas all those of S. neglecta (except for two samples that did not survive the winter) and the remaining individuals of $S$. ruderalis started to bloom between 9 and 16 April 2018. It is likely, however, that garden conditions affected their phenology. For example, artificial conditions reportedly prevent the flowering of S. neglecta (Whitehead \& Sinha 1967) and caused all the taxa in our experiment to flower earlier in spring than plants growing in situ. We also observed S. ruderalis flowering in autumn in its original environment in the city of České Budějovice. In general, our observations on phenology are in line with published data: S. neglecta, S. pallida and "S. media" with $2 \mathrm{n}=44$ (i.e. probably $S$. ruderalis) are mostly winter annuals, whereas $S$. media with $2 \mathrm{n}=40$ (i.e. S. media s. str.) is a summer annual (Peterson 1936, Morton 2005).

\section{Stellaria ruderalis M. Lepší, P. Lepší, Z. Kaplan et P. Koutecký spec. nova (Figs 6-8)}

D e s c r i p t i o n: Winter annuals, short-lived, often yellowish-green, much branched, up to $80 \mathrm{~cm}$ tall. Stems ascending, with one line of hairs along each internode, eglandular. Lowermost leaves petiolate with ovate to elliptical laminae and pubescent petioles; middle and upper leaves and bracts sessile, laminae ovate to ellipti$\mathrm{cal}$, acute to acuminate, pointed, rounded to rarely subcordate at base, entire, pubescence on midribs and glands on margins; bracts of the first flower (1.0-) 1.4-2.5 (-5.0) cm long and (0.4-) 0.8-1.2 (-2.0) cm wide. Flowers in terminal dichasia, initially condensed, later \pm lax, with one line of hairs and no or few glands on each internode; ratio of lengths of the first internodes of dichasium branches (0.7-) 1.1-1.3 (-1.8) cm. Pedicels reflexed after anthesis and erect after fruiting, (1.6-) 2.0-2.8 (-4.0) cm long, (0.16-) 0.24-0.32 (-0.48) $\mathrm{mm}$ wide, with one line of dense hairs and an admixture of scattered glands. Sepals free, lanceolate to ovate-lanceolate, (3.9-) 4.9-5.5 (-6.2) mm long, glandular-pubescent. Petals 5, white, deeply bifid, often with lobes unevenly long, (2.3-) 3.5-4.1 (-4.8) mm long, shorter than or as long as sepals. Stamens 3-5 (-10) with purpleviolet anthers. Styles 3, ascending, rarely erect, with only the apex revolute. Capsules (5.5-) 6.0-6.4 (-7.0) mm long, somewhat longer than sepals, opening with 6 teeth. Seeds (1.1-) 1.2-1.3 (-1.5) mm long, flattened, almost circular, light-brown to brown, with 5-6 rows of tubercles on the dorsal surface, tubercles conical, lon- 


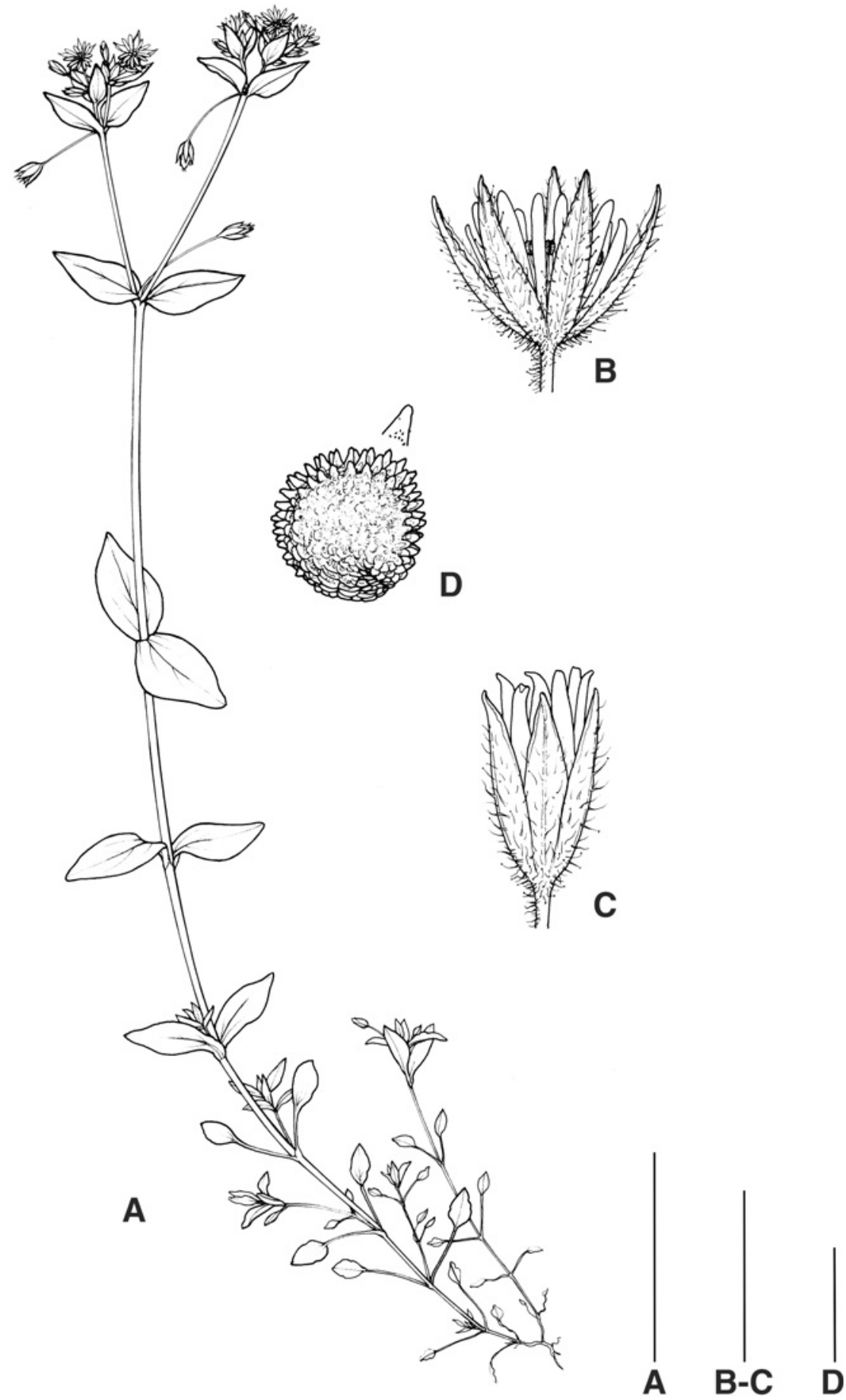

Fig. 6. - Stellaria ruderalis: A - habitus; B - flower; C - capsule; D - seed and detail of tubercle. Scale bars: A - $5 \mathrm{~cm}$; B-C $-5 \mathrm{~mm}$; D - $1 \mathrm{~mm}$. Drawn by A. Skoumalová. 

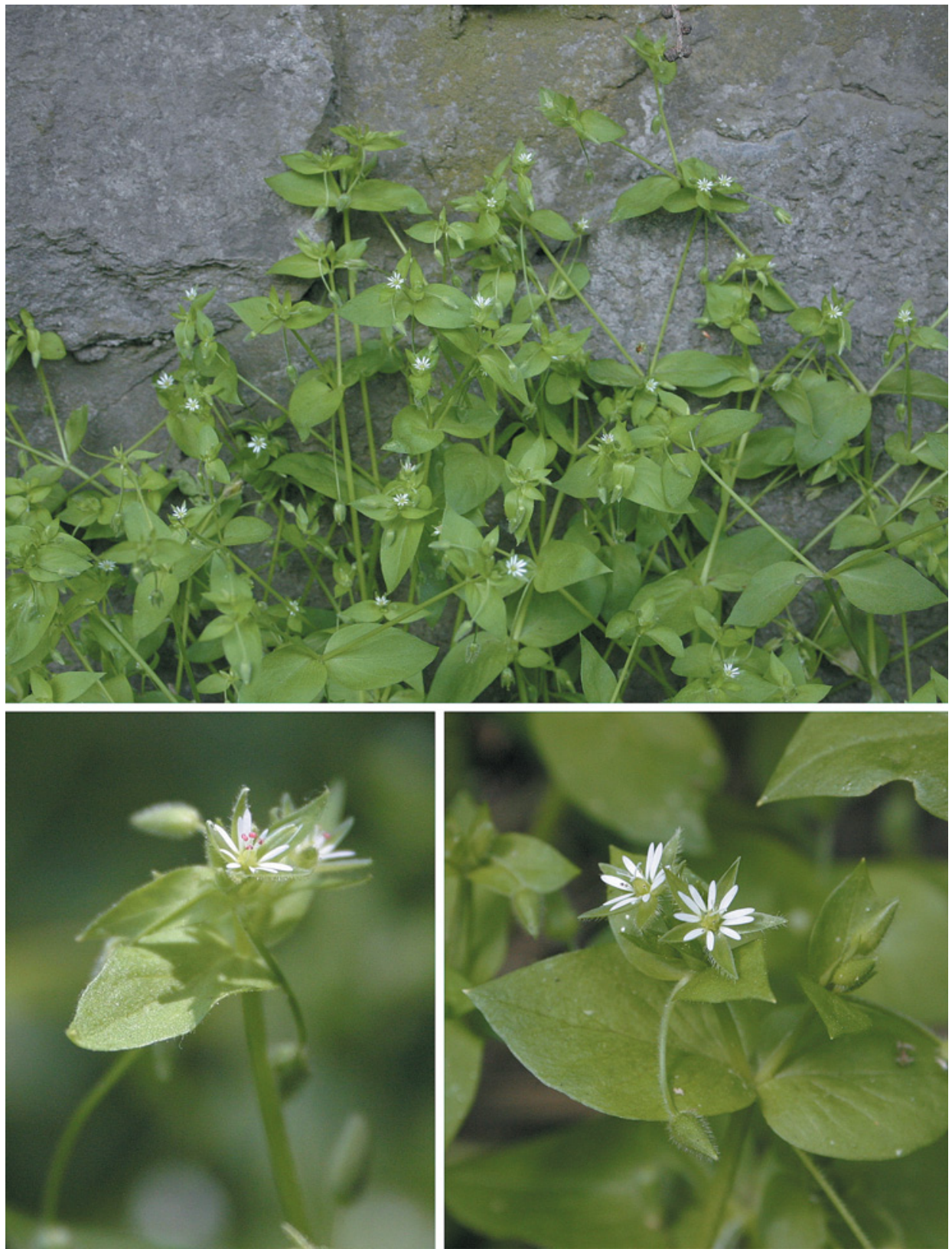

Fig. 7. - Stellaria ruderalis: top - habit, bottom left - flowers with closed anthers (Czech Republic, distr. Praha-západ, valley of the river Vltava near the village of Hradištko, 4952'08"N, 14²3'38"E, 24 V 2017, photographed by M. Lepší); bottom right - flowers with open anthers (Czech Republic, distr. České Budějovice, Hluboká nad Vltavou, Vondrov settlement, 4902'29"N, 14²4'51"E, 26 V 2017, photographed by M. Lepší). 


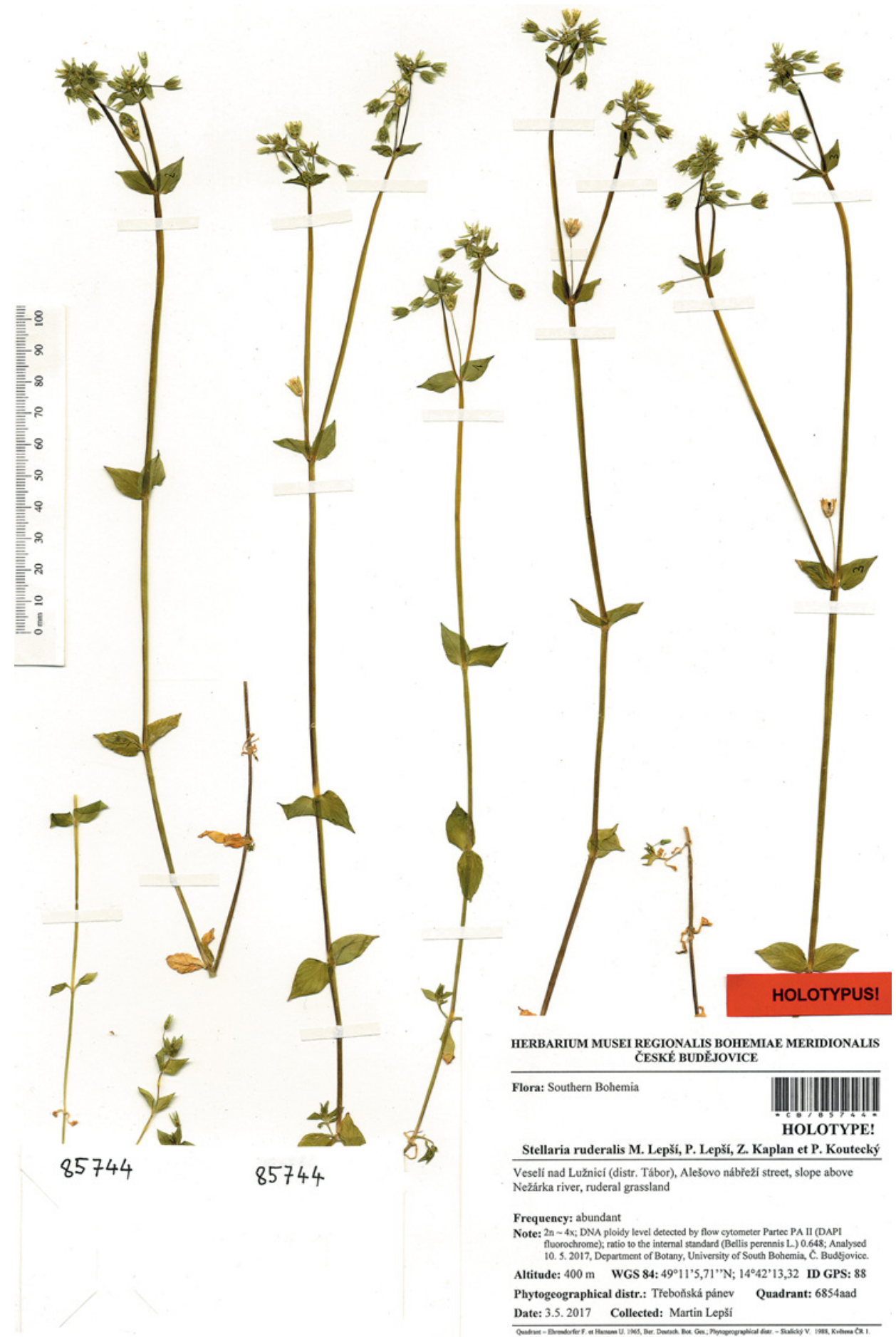

Fig. 8. - Holotype of Stellaria ruderalis. 
ger than wide, (0.08-) 0.11-0.14 (-0.18) mm long, with (0-) 4-10 (-15) small papillae on the front side of each tubercle. Number of chromosomes $2 \mathrm{n}=44$, tetraploid. Flowering IV-V.

H o l o t y p e: Czech Republic, southern Bohemia, Veselí nad Lužnicí (distr. Tábor): Alešovo nábřeží street, slope above Nežárka river, ruderal grassland; 400 m a.s.1., 49¹1'05.7"N, 14²4'13.3"E; abundant; 3 V 2017 leg. Martin Lepší; ID 88; CB No. 85744 (Fig. 8). - I s o t y p e: PR No. 929401.

Etymology: The epithet "ruderalis" refers to the ecological demands of this species, which occurs in a diversity of ruderal habitats. We propose the epithet "rumištní" for the Czech name.

\section{Taxonomy and similar species}

Stellaria ruderalis is morphologically intermediate between S. media and S. neglecta; however, in some characters (yellowish-green colour and condensed inflorescence) it may also resemble $S$. pallida, which seems to be one of the parents of this allopolyploid. In petal length and the number of stamens it resembles $S$. media, which differs significantly in having flat-topped or rounded, rarely shortly conical tubercles on the seeds that are usually as long as wide and with scattered to abundant papillae on their upper part (Figs 9-10). In contrast, S. ruderalis has conical and longer than wide tubercles on seeds, with no or few papillae on their surface. It should be noted that some capsules of $S$. ruderalis may contain a few seeds that have the same morphology as those of S. media; for reliable identification it is, therefore, necessary to examine several seeds per plant. Other less distinct characters of $S$. media are a darker (green up to dark green) colour and smaller size (up to $50 \mathrm{~cm}$ ), often prostrate stems, a lax inflorescence, usually broadly ovate leaves and bracts, and the first internodes of the inflorescence remarkably unevenly long. In $S$. ruderalis, these characters are: \pm yellowish-green plants, up to $80 \mathrm{~cm}$ tall, ascending, upper leaves and bracts ovate or elliptical, inflorescence at first usually condensed, and the first internodes of the inflorescence not remarkably unevenly long. Plants of $S$. neglecta are similar in size to those of $S$. ruderalis and there are long conical tubercles on their seeds. However, $S$. neglecta has usually more stamens (8-10) than $S$. ruderalis (3-10), longer petals (longer or \pm as long as sepals), more papillae on the tubercles on the seeds, thinner pedicels (see Table 3), a lax inflorescence, darker seeds and green coloured plants. Stellaria pallida is the most distinct taxon in the S. media group because it has small seeds whose length only slightly overlaps that of the other species (Whitehead \& Sinha 1967). Another significant character of S. pallida is minute or absent petals; however, petals may rarely be absent also in S. media and S. neglecta (Whitehead $\&$ Sinha 1967). The small size of the plants (up to $35 \mathrm{~cm}$ ), ascending and reflexed stigmas, and light-coloured seeds can be used as supplementary characters for the differentiation of $S$. pallida from $S$. ruderalis, which has longer stems (up to $80 \mathrm{~cm}$ ), mostly ascendant to rarely erect stigmas with only the apex revolute and light-brown to brown seeds.

Taxonomic relationships of $S$. ruderalis with the eutetraploid forms $(2 \mathrm{n}=44)$ of $S$ media and S. neglecta in Italy (Scholte 1978) is unclear. This author reports intermediate forms between them and also transitional morphotypes to $S$. media $(2 n=40)$ and even to $S$. pallida $(2 \mathrm{n}=22)$. Our samples from southern Europe (see Appendix 2) indicate that at least some of the taxonomically unclear plants from Italy may belong to the newly recognized species. Stellaria ruderalis is relatively variable and very phenotypically plastic and to some extent it could resemble a transitional form between the three traditionally 


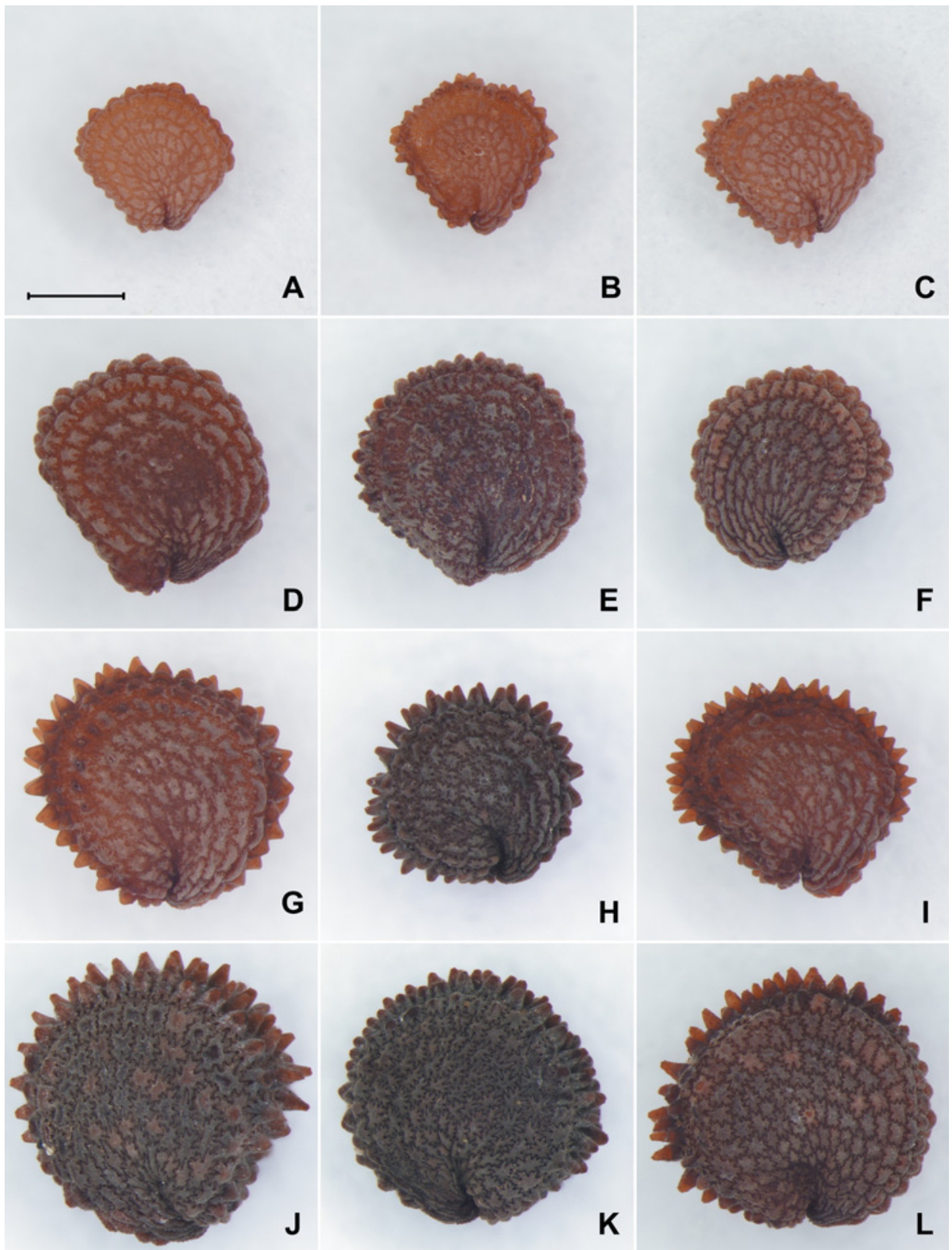

Fig. 9. - Variation of seeds within the Stellaria media group: first line - S. pallida, A - ID 86, B - ID 93, C - ID 99; second line - S. media, D - ID 90, E - ID 112, F - ID 128; third line - S. ruderalis, G - ID 80, H - ID 88, I - ID 107; fourth line - S. neglecta, J - ID 127, K - ID 132, L - ID 135. Scale bar identical for all figures $=0.5 \mathrm{~mm}$. See Appendix 1 for details of the localities. 


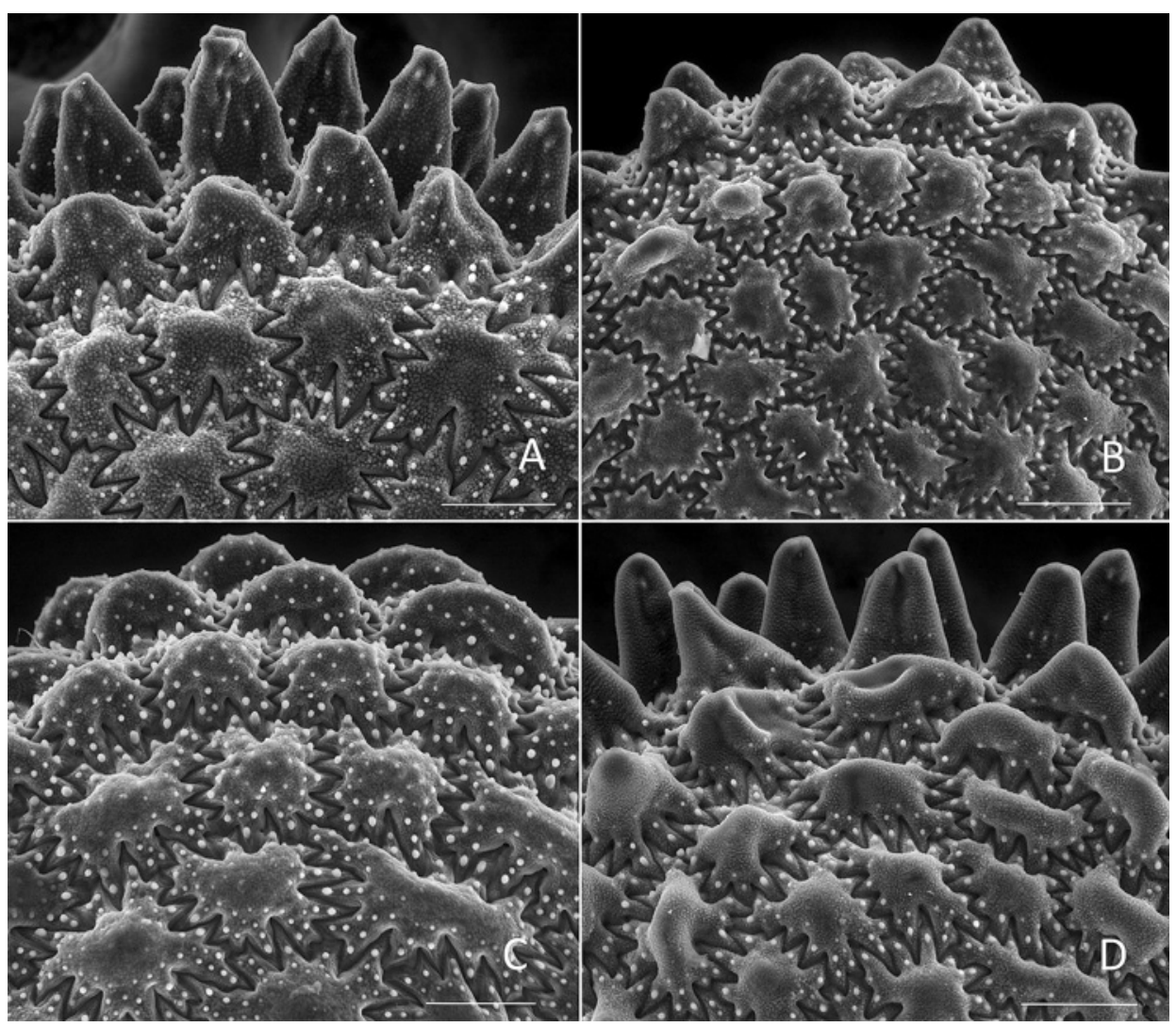

Fig. 10. - Scanning electron microscopy of tubercles on the dorsal surface of seeds of the Stellaria media group: A - S. neglecta ID 135, tubercles long, conical, longer than wide, with scattered papillae on the upper part of their surface; B - S. pallida ID 99, tubercles shortly conical, as long as wide or slightly longer than wide, with scattered papillae on the upper part of their surface; C - S. media ID 90, tubercles short, rounded, up to as long as wide, with scattered papillae on the upper part of their surface; D - S. ruderalis ID 88, tubercles on seeds long, conical, longer than wide, with rare or no papillae on the upper part of their surface. Scale bars = $100.0 \mu \mathrm{m}$. See Appendix 1 for details of the localities.

recognised taxa of $S$. media agg. The alternative (and not mutually exclusive) option is that the variability of the $S$. media agg. in southern Europe is more complex and boundaries between species are blurred.

\section{Ecology}

Stellaria ruderalis is a ruderal species. It grows mainly in disturbed ruderal open or semiopen communities such as grasslands and edges of ruderal scrub and diverse types of forests and tree plantations. It often occurs along roads and railways. It is also commonly recorded along rivers, especially in urban areas and inhabits (besides ruderal habitats) riparian semi-natural forest and shrub communities. This species grows mainly on moist to wet nutrient-rich soils on diverse, usually anthropogenic substrates, but is also recorded 
on alluvial deposits. We did not record $S$. ruderalis as a weed of crops, which is one of the typical habitats of $S$. media. However, both species can co-occur in other ruderal communities. These two species have very similar ecological demands. By contrast, S. neglecta is a species of semi-natural habitats such as wet to mesic, usually riparian forests and scrub. However, it also often grows together with $S$. ruderalis, especially adjacent to roads or railways or in the vicinity of these habitats. Finally, S. pallida is a species of sandy soils, but currently is spreading in urban lawns in the Czech Republic (Hadinec \& Kaplan 2012) where we also recorded it occasionally together with S. ruderalis. The ecological amplitude of the newly recognized species is broad and overlaps that of the other species, especially, S. media.

\section{Distribution}

The distribution of $S$. ruderalis is incompletely known. In the Czech Republic, it is common in southern and central Bohemia, and also occurs in southern Moravia. It is currently spreading along roads, railways and rivers. The dynamics of its spread, residential status and distribution in the Czech Republic deserve further research. Outside this country we recorded this species in southern Slovakia, Lower Austria, Hungary, Slovenia, Croatia, Serbia, Italy including Sardinia and Greece (locality details in Appendix 2). It is probably a hitherto overlooked widespread species, especially in southern Europe.

\section{Key to the identification of species of the Stellaria media group}

We include all the relevant characters identified by the morphometric analyses along with our field observations and previously published data in the following key. For safe identification, it is essential to use mean values of 3-5 measurements of the same character from one individual. Seeds have to be ripe and flowers must not come from the end of the flowering period of an individual. It can be difficult to separate these taxa without good flowering and fruiting material and the identification of poor herbarium specimens is particularly difficult.

1a Petals absent or very short, up to one-third of the length of sepals; seeds up to $1 \mathrm{~mm}$ long. - Plants usually low, up to $35 \mathrm{~cm}$ high, yellowish-green; upper leaves and bracts ovate or elliptical; inflorescence usually condensed, the first internodes of dichasium branches not remarkably unevenly long; pedicels not remarkably thin, (0.16-) 0.24-0.40 (-0.56) mm wide; stamens (1-) 2-3 (-4); stigmas ascending and reflexed; seeds light brown to brown, tubercles on seeds short, rounded to shortly conical, usually as long as wide or slightly longer than wide, with scattered papillae on the upper part of their surface

1b Petals usually present, one-third shorter, as long as or longer than sepals; seeds usually longer than $1 \mathrm{~mm}$.... 2

2a Stamens (8-) 10, petals as long or slightly longer than sepals; pedicels remarkably thin, $0.16-0.24 \mathrm{~mm}$ wide. - Plants tall, up to $80 \mathrm{~cm}$ high, green; upper leaves and bracts ovate or elliptical; inflorescence lax, the first internodes of dichasium branches not remarkably unevenly long; stigmas mostly erect with only the apex revolute; seeds \pm dark brown, tubercles on seeds high, conical, higher than wide, with scattered papillae on upper part of their surface

S. neglecta

2b Stamens usually less than 8, petals shorter or as long as sepals, pedicels not remarkably thin, (0.16-) $0.24-0.40(-0.48) \mathrm{mm}$ wide

3a Tubercles on seeds long, conical, longer than wide, with a few or no papillae on the upper part of their surface. - Plants up to $80 \mathrm{~cm}$ high, \pm yellowish-green; upper leaves and bracts ovate or elliptical; inflorescence at first usually condensed, the first internodes of dichasium branches not remarkably unevenly long; pedicels not remarkably thin, (0.16-) 0.24-0.32 (-0.48) mm wide; petals shorter or as long as sepals; stamens 3-5 (-10); stigmas mostly ascendent to rarely erect, with only the apex revolute; seeds light brown to dark brown 
3b Tubercles on seeds short, flat-topped or rounded, rarely shortly conical, usually as high as wide, with scattered to abundant papillae on the upper part of their surface. - Plants low (and often prostrate) to tall, up to $50 \mathrm{~cm}$ high, green to dark green; upper leaves and bracts often broadly ovate or elliptical; inflorescence not condensed, the first internodes of dichasium branches remarkably unevenly long; pedicels not remarkably thin, (0.16-)0.32-0.40(-0.48) mm wide; petals shorter or as long as sepals; stamens 3-5(-10); stigmas mostly erect, with only the apex revolute; seeds brown to dark brown

S. media

\section{Acknowledgements}

We wish to thank A. Skoumalová for drawing the illustrations, J. Machač for photographs of the seeds, P. Neumann for enabling us to use the fluorescence microscope at the Institute of Plant Molecular Biology and J. Košnar for advice on molecular analyses. Fred Rooks and Tony Dixon edited the English of the manuscript. We are grateful to K. Boublík for his kind help in the field. This study was supported by the Centre of Excellence PLADIAS, project no. 14-36079G from the Czech Science Foundation. M. Lučanová and Z. Kaplan were also supported by long-term research development project no. RVO 67985939 of the Czech Academy of Sciences.

\section{Souhrn}

V příspěvku je popsán nový druh ptačince, Stellaria ruderalis M. Lepší et al. (ptačinec rumištní), z okruhu ptačince prostředního (Stellaria media agg.). Rozlišení nového taxonu podpořily všechny použité biosystematické analýzy, jejichž výsledky byly převážně v souladu s publikovanými informacemi o zbývajících druzích skupiny. Průtokovou cytometrií bylo zjištěno, že $S$. ruderalis je na rozdíl od diploidních druhů $S$. pallida a $S$. neglecta tetraploidní, a od Stellaria media, který je rovněž tetraploidní, se liší relativní velikostí genomu. Tomu odpovídají i výsledky počítání chromosomů, které ukázaly, že $S$. media má somatický počet chromozomů $2 n=40, S$. ruderalis $2 n=44$, S. pallida $2 n=22$ a S. neglecta $2 n=22$. Sekvenování ITS úseku jaderné ribozomální DNA potvrdilo, že všechny taxony se od sebe liší. Tetraploidní taxony jsou zřejmě allopolyploidního původu: S. media mezi $S$. neglecta a dosud neznámým druhým taxonem, zatímco rodiči $S$. ruderalis jsou pravděpodobně $S$. pallida a taxon blízký S. neglecta (ale sekvence jsou mírně odlišné od středoevropských rostlin). Mnohorozměrné morfometrické analýzy potvrdily, že se všechny čtyři taxony vzájemně liší. Prostřednictvím zahradního experimentu byly prokázány i významné odlišnosti ve fenologii některých druhů. Druh $S$. media klíčil a kvetl tentýž rok po vysetí, zatímco zbývající druhy kvetly až následující rok. Semena $S$. neglecta a část semen $S$. media klíčila mezi 7. a 22. dnem po vysetí, S. pallida a $S$. ruderalis a zbývající semena $S$. media mezi 48. a 77. dnem po vysetí. Stellaria ruderalis je typický ruderální druh lesního i nelesního prostředí. V současnosti v České republice roste podél silnic, železnic a podél vodních toků zvláště v blízkosti dopravních komunikací a měst. Jeho ekologická amplituda je široká a značně se překrývá s ostatními druhy agregátu. Na rozdíl od S. media nebyl doposud zaznamenán jako polní plevel, nicméně běžně s ním roste na ruderálních lokalitách a směsné populace vytváří i se zbývajícími druhy (obzvláště se $S$. neglecta). V České republice byl doposud pozorován ve stř̌edních a jižních Čechách a na jižní Moravě, ale je velmi pravděpodobné, že roste i v jiných částech státu a v současnosti se v České republice šîrí. Celkové rozšíření není známé, nicméně vše nasvědčuje tomu, že to je široce rozšîřený druh. Námi byl zaznamenán na Slovensku, v Rakousku, Mad’arsku, Slovinsku, Chorvatsku, Srbsku, Itálii a Řecku.

K určení jednotlivých druhů okruhu ptačince prostředního poslouží následující klíč. Semena musí být zralá a pocházet z více tobolek, květy nesmějí pocházet ze závěrečných fází kvetení. Je vhodné používat průměrné hodnoty získané z 3-5 různých orgánů stejného jedince. K určení množství papilek na hřbetních papilách semen je nutné použít silnou binokulární lupu.

1a Korunní lístky chybějí nebo velmi krátké, nanejvýš dosahují 1/3 délky kališních lístků; semena nanejvýš 1 mm dlouhá. - Rostliny nízké, nanejvýš 35 cm vysoké, žlutozelené; horní listy a listeny vejčité až eliptické; květenství zpravidla klubkovitě stažená, první internodia větví dicházia nejsou nápadně nestejně dlouhá; květní stopky nejsou nápadně tenké, $(0,16-)$ 0,24-0,40 (-0,56) mm široké; tyčinky v počtu (1-) 2-3 (-4); zralá semena žlutohnědá až hnědá, jejich hřbetní papily polokulovité až krátce kuželovité, zpravidla stejně vysoké jako široké nebo o něco vyšší než široké, v horní části s roztroušenými drobnými papilkami

1b Korunní lístky většinou přítomné, nanejvýš o 1/3 kratší než kališní lístky; zralá semena delší než 1 mm ....... 2

2a Tyčinek (8-) 10, korunní lístky \pm stejně dlouhé nebo mírně přesahující kališní lístky. - Rostliny až 80 cm vysoké, zelené; horní listy a listeny vejčité až eliptické; květenství řídká, první internodia větví dicházia nejsou nápadně nestejně dlouhá; květní stopky nápadně tenké, $0,16-0,24 \mathrm{~mm}$ široké; semena \pm tmavě 
hnědá, hřbetní papily semen kuželovité, vyšší než široké, v horní části s roztroušenými drobnými papilkami S. neglecta

2b Tyčinek zpravidla méně než 8, korunní lístky stejně dlouhé nebo kratší než kališní lístky ........................ 3

3a Hřbetní papily semen kuželovité, zpravidla vyšší než široké, v horní části s ojedinělými nebo žádnými drobnými papilkami. - Rostliny zpravidla až $80 \mathrm{~cm}$ vysoké, \pm žlutozelené; horní listy a listeny vejčité až eliptické, květenství zpravidla zpočátku klubkovitě stažená, první internodia větví dicházia nejsou nápadně nestejně dlouhá; květní stopky nejsou nápadně tenké, $(0,16-)$ 0,24-0,32 $(-0,48)$ mm široké; tyčinky 3-5 (-10); zralá semena hnědá až tmavě hnědá

S. ruderalis

3b Hřbetní papily zpravidla polokulovité, vzácněji až krátce kuželovité, zpravidla stejně vysoké jako široké, v horní části s roztroušenými až hojnými drobnými papilkami. - Rostliny nízkého (často poléhavého) až vysokého vzrůstu, nanejvýš $50 \mathrm{~cm}$ vysoké, zelené až tmavě zelené; horní listy a listeny často široce vejčité až eliptické; květenství nejsou klubkovitě stažená, první internodia větví dicházia často nápadně nestejně dlouhá; květní stopky nejsou nápadně tenké, $(0,16-)$ 0,32-0,40 $(-0,48)$ mm široké; tyčinky 3-5 (-10); zralá semena hnědá až tmavě hnědá S. media

\section{References}

Belkin D. L. (2011) Genus Stellaria (Caryophyllaceae) in Altai mountain country. - Turczaninowia 14: 9-17.

Boublík K. \& Petřík P. (2013) Stellaria neglecta - ptačinec přehlížený. - In: Lepší M. \& Lepší P. (eds), Nálezy zajímavých a nových druhů v květeně jižní části Čech XIX [Records of interesting and new plants in the South Bohemian flora XIX], Sborník Jihočeského muzea v Českých Budějovicích, Přírodní Vědy 53: 70-85.

Chater A. O. \& Heywood V. H. (1964) Stellaria L. - In: Tutin T. G., Heywood V. H., Burges N. A., Valentine D. H., Walters S. M. \& Webb D. A. (eds), Flora Europaea 1: 133-136, Cambridge University Press, Cambridge.

Chen S.-L. \& Rabeler R. K. (2001) Stellaria. - In: Wu Z.-Y., Raven P. H. \& Hong D.-Y. (eds), Flora of China 6: 11-29, Science Press, Beijing \& Missouri Botanical Garden, St. Louis.

Danihelka J., Chrtek J. jr. \& Kaplan Z. (2012) Checklist of vascular plants of the Czech Republic. - Preslia 84: 647-811.

Doležel J., Greilhuber J. \& Suda J. (2007) Estimation of nuclear DNA content in plants using flow cytometry. Nature Protocols 2: 2233-2244.

Doyle J. J. \& Doyle J. L. (1987) A rapid DNA isolation procedure for small quantities of fresh leaf tissue. Phytochemical Bulletin 19: 11-15.

Dvořáková M. (1990) Stellaria L. - ptačinec. - In: Hejný S., Slavík B., Hrouda L. \& Skalický V. (eds), Květena České republiky [Flora of the Czech Republic] 2: 123-134, Academia, Praha.

Ehrendorfer F. \& Hamann U. (1965) Vorschlage zu einer floristischen Kartierung von Mitteleuropa. - Berichte der Deutschen Botanischen Gesellschaft 78: 35-50.

Fajmon K. (2007) Stellaria pallida (Dumort.) Crép. - In: Hadinec J. \& Lustyk P. (eds), Additamenta ad floram Reipublicae Bohemicae. VI. [Additions to the flora of the Czech Republic. VI.], Zprávy České botanické společnosti 42: 329-332.

Fischer M. A., Oswald K. \& Adler W. (eds) (2008) Exkursionsflora für Österreich, Liechtenstein und Südtirol. Ed. 3. - Biologiezentrum der Oberösterreichischen Landesmuseen, Linz.

Greenberg A. K. \& Donoghue M. J. (2011) Molecular systematics and character evolution in Caryophyllaceae. - Taxon 60: 1637-1652.

Hadinec J. \& Kaplan Z. (2012) Stellaria pallida (Dumort.) Crép. - In: Hadinec J. \& Lustyk P. (eds), Additamenta ad floram Reipublicae Bohemicae. X. [Additions to the flora of the Czech Republic. X.], Zprávy České botanické společnosti 47: 138-142.

Hall T. A. (1999) BioEdit: a user-friendly biological sequence alignment editor and analysis program for Windows 95/98/NT. - Nucleic Acids Symposium 41: 95-98.

Huson D. H. \& Bryant D. (2006) Application of phylogenetic networks in evolutionary studies. - Molecular Biology and Evolution 23: 254-267.

Jalas J. \& Suominen J. (eds) (1983) Atlas Florae Europaeae. Distribution of vascular plants in Europe. 6. Caryophyllaceae (Alsinoideae and Paronychioideae). - The Committee for Mapping the Flora of Europe \& Societas Biologica Fennica Vanamo, Helsinki.

Kamari G., Felber F. \& Garbari F. (1996) Mediterranean chromosome number reports - 6. - Flora Mediterranea 6: 223-337. 
Keshavarzi M. \& Esfandani Bozchaloyi S. (2014) Chromosome numbers for some Stellaria L. (Caryophyllaceae) species and related taxa in Iran. - The Iranian Journal of Botany 20: 36-40.

King R. A., Gornall R. J., Preston C. D. \& Croft M. (2001) Molecular confirmation of Potamogeton $\times$ bottnicus (P. pectinatus $\times$ P. vaginatus, Potamogetonaceae) in Britain. - Botanical Journal of the Linnean Society 135: 67-70.

Koch M. A., Dobeš C. \& Mitchell-Olds T. (2003) Multiple hybrid formation in natural populations: concerted evolution of the internal transcribed spacer of nuclear ribosomal DNA (ITS) in North American Arabis divaricarpa (Brassicaceae). - Molecular Biology and Evolution 20: 338-350.

Lepš J. \& Šmilauer P. (2003) Multivariate analysis of ecological data using CANOCO. - Cambridge University Press, Cambridge.

Löve A. \& Löve D (1975) Cytotaxonomical atlas of the Arctic flora. - Cramer, Vaduz.

Mandáková T. \& Lysak M. A. (2016) Chromosome preparation for cytogenetic analyses in Arabidopsis. - Current Protocols in Plant Biology 1: 43-51.

Marhold K. (2011) Caryophyllaceae. - In: Euro+Med PlantBase - the information resource for Euro-Mediterranean plant diversity, URL: http://ww2.bgbm.org/EuroPlusMed/ (accessed 2019).

Měsíček J. \& Jarolímová V. (1992) List of chromosome numbers of the Czech vascular plants. - Academia, Praha.

Miller C. H. \& West J. G. (2012) A revision of the genus Stellaria (Caryophyllaceae) in Australia. - Journal of the Adelaide Botanic Gardens 25: 27-54.

Morton J. K. (2005) Stellaria. - In: Flora of North America Editorial Committee (eds), Flora of North America north of Mexico 5: 96-114, New York and Oxford.

R Development Core Team (2011) R: A language and environment for statistical computing. - R Foundation for Statistical Computing, Vienna, URL: http://www.R-project.org.

Peterson D. (1936) Stellaria Studien. Zur Zytologie, Genetik, Ökologie and Systematik der Gattung Stellaria, insbesondere der media-Gruppe. - Botaniska Notiser 88: 281-419.

Rice A., Glick L., Abadi S., Einhorn M., Kopelman N. M., Salman-Minkov A., Mayzel J., Chay O. \& Mayrose I. (2015) The Chromosome Counts Database (CCDB) - a community resource of plant chromosome numbers. - New Phytologist 206: 19-26.

Scholte G. A. M. (1978) Biosystematic studies in the collective species Stellaria media (L.) Vill. 1. - Proceedings van de Koninklijke Nederlandse Akademie van Wetenschappen, Series C Biological and Medical Sciences 81: 442-456.

Schönswetter P., Suda J., Popp M., Weiss-Schneeweiss H. \& Brochmann C. (2007) Circumpolar phylogeography of Juncus biglumis (Juncaceae) inferred from AFLP fingerprints, cpDNA sequences, nuclear DNA content and chromosome numbers. - Molecular Phylogenetics and Evolution 42: 92-103.

Skalický V. (1988) Regionálně fytogeografické členění [Regional phytogeographical division]. - In: Hejný S., Slavík B., Chrtek J., Tomšovic P. \& Kovanda M. (eds), Květena České socialistické republiky [Flora of the Czech Socialist Republic] 1: 103-121, Academia, Praha.

Stace C. (2010) New Flora of the British Isles. - Cambridge University Press, Cambridge.

Thiers B. (2019) Index Herbariorum: a global directory of public herbaria and associated staff. - New York Botanical Garden's Virtual Herbarium, URL: http://sweetgum.nybg.org/science/ih/ (accessed January 2019).

Turkington R., Kenkel N. C. \& Franko G. D. (1980) The biology of Canadian weeds. 42. Stellaria media (L.) Vill. - Canadian Journal of Plant Science 60: 981-992.

van Kleunen M., Pyšek P., Dawson W., Essl F., Kreft H., Pergl J., Weigelt P., Stein A., Dullinger S., König C., Lenzner B., Maurel N., Moser D., Seebens H., Kartesz J., Nishino M., Aleksanyan A., Ansong M., Antonova L. A., Barcelona J. F., Breckle S. W., Brundu G., Cabezas F. J., Cárdenas D., Cárdenas-Toro J., Castaño N., Chacón E., Chatelain C., Conn B., de Sá Dechoum M., Dufour-Dror J.-M., Ebel A. L., Figueiredo E., Fragman-Sapir O., Fuentes N., Groom Q. J., Henderson L., Inderjit, Jogan N., Krestov P., Kupriyanov A., Masciadri S., Meerman J., Morozova O., Nickrent D., Nowak A., Patzelt A., Pelser P. B., Shu W., Thomas J., Uludag A., Velayos M., Verkhosina A., Villaseñor J. L., Weber E., Wieringa J. J., Yazlýk A., Zeddam A., Zykova E. \& Winter M. (2019) The Global Naturalized Alien Flora (GloNAF) database. - Ecology 100: e02542.

Venables W. N. \& Ripley B. D. (2002) Modern applied statistics with S. - Springer, New York.

White T. J., Bruns T. D., Lee S. \& Taylor J. (1990) Amplification and direct sequencing of fungal ribosomal RNA genes for phylogenetics. - In: Innis M. A., Gelfand D. H., Sninsky J. J. \& White T. J. (eds), PCR protocols: a guide to methods and applications, p. 315-322, Academic Press, New York. 
Whitehead F. H. \& Sinha R. P. (1967) Taxonomy and taximetrics of Stellaria media (L.) Vill., S. neglecta Weihe and S. pallida (Dumort.) Piré. - New Phytologist 66: 769-784.

Received 25 August 2019 Revision received 31 October 2019

Accepted 4 November 2019

Appendix 1. - Locality details and herbarium vouchers of all the individuals of the species of Stellaria sampled for all the analyses used in this study. The specimens are sorted according to the Czech regionalphytogeographical classification system (Skalický 1988) and according to quadrant numbers of the Central European grid mapping system (Ehrendorfer \& Hamann 1965). Names of collectors are abbreviated as follows: $\mathrm{KB}=\mathrm{K}$. Boublík, $\mathrm{ML}=\mathrm{M}$. Lepší, PK = P. Kunzová, PL = P. Lepší. Other abbreviations are: FCM - value of the sample/standard ratio from flow cytometry analysis, ID - collection numbers of specimens. Accession numbers in the CB herbarium (acronym according to Thiers 2019) follow the initials of collectors.

\section{Stellaria media}

8. Český kras: Srbsko (distr. Beroun): ca $660 \mathrm{~m}$ NE of centre of bridge over Berounka river, road ditch, scattered, 240 m a.s.1., 4956'27.1"N, 1408'20.1"E, 6050d, FCM 0.624, ID 76 (30 IV 2017 leg. ML \& PL, CB 85739). - 32. Křivoklátsko: Skryje (distr. Rakovník): Zbirožský potok valley ca $950 \mathrm{~m}$ WSW of church in village, Galio-Urticetea, abundant, 330 m a.s.1., 49 57'48.2"N, 13²4'14.8"E, 6048b, FCM 0.624, ID 128 (17 V 2017 leg. ML, PL \& KB, CB 85788). - 35c. Příbramské Podbrdsko: Bytíz (distr. Příbram): ca 1.1 m SW of centre of village, heap of earth, rare, $575 \mathrm{~m}$ a.s.1., 4940'23.8"N, 1403'53.8"E, 6350a, FCM 0.620, ID 123 (17 V 2017 leg. ML \& PL, CB 85779). - 37l. Českokrumlovské Předšumaví: Český Krumlov (distr. Český Krumlov): ca $70 \mathrm{~m} \mathrm{SE}$ of railway station, railway embankment, scattered, $540 \mathrm{~m}$ a.s.1., 4849'20.0"N, 14²19'04.7"E, 7151d, FCM 0.627, ID 115 (11 V 2017 leg. ML, CB 85774). - 37p. Novohradské podhůří: Doubravice (distr. České Budějovice): ca $380 \mathrm{~m} \mathrm{SW}$ of chapel in centre of village, road ditch, scattered, $470 \mathrm{~m}$ a.s.1., $48^{\circ} 56^{\prime} 01.3^{\prime \prime} \mathrm{N}$, 14³0'21.7"E, 7053c, FCM 0.624, ID 78 (2 V 2017 leg. ML, CB 85747). - Nová Ves (distr. České Budějovice): ca $730 \mathrm{~m} \mathrm{NW}$ of railway station, disturbed grassland at road edge, several individuals, $470 \mathrm{~m}$ a.s.1., 48 $55^{\circ} 36.9^{\prime \prime} \mathrm{N}$, 14³1'27.6"E, 7053c, FCM 0.618, ID 94 (4 V 2017 leg. ML, CB 85756). - 38. Budějovická pánev: Bavorovice (distr. České Budějovice): ca $820 \mathrm{~m}$ NNW of chapel in village, road edge, scattered, $380 \mathrm{~m}$ a.s.1., $49^{\circ} 01^{\prime} 58.1^{\prime \prime} \mathrm{N}$, 14²6'26.1"E, 6952d, FCM 0.623, 2n = 40, ID 112 (10 V 2017 leg. ML, CB 85778). - České Vrbné (distr. České Budějovice): ca $620 \mathrm{~m}$ NE of chapel in centre of village, disturbed grassland on river embankment, several individuals, $375 \mathrm{~m}$ a.s.1., 4900'44.0" $\mathrm{N}$, 14$^{\circ} 27^{\prime} 19.5^{\prime \prime} \mathrm{E}, 6952 \mathrm{~d}$, FCM 0.623, ID 110 (10 V 2017 leg. ML, CB 85777). - České Budějovice (distr. České Budějovice): slope above Malše river ca $300 \mathrm{~m}$ NNW of Malý jez weir, grassland below trees, rare, 390 m a.s.1., 48 $57^{\prime} 48.7^{\prime \prime} \mathrm{N}, 1^{\circ} 28^{\prime} 36.2^{\prime \prime E}, 7052$ b, FCM 0.622, ID 102 (5 V 2017 leg. ML, CB 85763). - 39. Třeboňská pánev: Veselí nad Lužnicí (distr. Tábor): Na Pískách street, urban lawn, scattered, $410 \mathrm{~m}$ a.s.1., 49¹1'07.3"N, 14²4'13.0"E, 6854a, FCM 0.624, 2n = 40, ID 87 (3 V 2017 leg. ML, CB 85741). - Vlkov (distr. Tábor): near railway stop, ruderal open grassland, rare, $415 \mathrm{~m}$ a.s.1., 49 $08^{\prime} 53.9^{\prime \prime} \mathrm{N}$, 1443'42.2"E, 6854c, FCM 0.625, ID 90 (3 V 2017 leg. ML, CB 85745).

\section{Stellaria neglecta}

8. Český kras: Sedlec (distr. Beroun): ca $840 \mathrm{~m}$ NE of chapel in village, road edge at forest edge, scattered, $250 \mathrm{~m}$ a.s.1., 49 58'57.7"N, 1408'49.8"E, 6050b, FCM 0.368, 2n = 22, ID 120 (12 V 2017 leg. ML, CB 85772). - Svatý Jan pod Skalou (distr. Beroun): ca $310 \mathrm{~m} \mathrm{SW}$ of church in village, forest edge, scattered, $235 \mathrm{~m}$ a.s.1., 4958'02.9"N, 1407'49.9"E, 6050b, FCM 0.372, ID 118 (12 V 2017 leg. ML, CB 85770). - Svatý Jan pod Skalou (distr. Beroun): ca $400 \mathrm{~m}$ NNW of church in village, road edge at base of slope, scattered, $250 \mathrm{~m}$ a.s.1., 4958'21.3"N, 1408'01.4"E, 6050b, FCM 0.367, ID 119 (12 V 2017 leg. ML, CB 85771). - Beroun-Hostim (distr. Beroun): E edge of village, edge of forest and dry grassland, abundant, $255 \mathrm{~m}$ a.s.1., 49 ${ }^{\circ} 57^{\prime} 32.5^{\prime \prime} \mathrm{N}$, 
1408'06.6"E, 6050b, FCM 0.371, ID 117 (12 V 2017 leg. ML, CB 85769). - Srbsko (distr. Beroun): ca 1 km $\mathrm{NE}$ of centre of bridge over Berounka river, road edge in floodplain of brook, scattered, $250 \mathrm{~m}$ a.s.1., 4956'32.5"N, 1408'37.9"E, 6050d, FCM 0.370, ID 116 (12 V 2017 leg. ML, CB 85768). - 32. Křivoklátsko: Branov (distr. Rakovník): V Luhu settlement W of village, Robinia pseudacacia growth, abundant, $275 \mathrm{~m}$ a.s.1., 5000'41.4"N, 1350'12.6"E, 5949c, FCM 0.372, ID 124 (17 V 2017 leg. ML, PL \& KB, CB 85750). - Skryje (distr. Rakovník): Zbirožský potok valley ca $950 \mathrm{~m} \mathrm{WSW}$ of church in village, Robinia pseudacacia growth, scattered, 330 m a.s.1., 4957'48.0"N, 134'14.6"E, 6048b, FCM 0.375, ID 126 (17 V 2017 leg. ML, PL \& KB, CB 85790). - Skryje (distr. Rakovník): Zbirožský potok valley ca $1.6 \mathrm{~km} \mathrm{SW}$ of church in village, Galio-

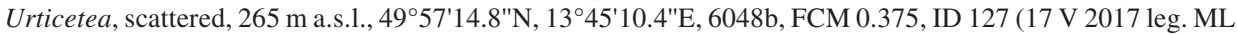
\& PL, CB 85789). - Broumy (distr. Beroun): Úpořský potok valley ca $590 \mathrm{~m} \mathrm{~S}$ of summit of Průhonek hill, scree forest with dominating Fraxinus excelsior, scattered, $310 \mathrm{~m}$ a.s.1., 4957'48.1"N, 13⒋ $48^{\prime} 51.6^{\prime \prime} \mathrm{E}, 6048 \mathrm{~b}$, FCM 0.371, ID 125 (17 V 2017 leg. ML, PL \& KB, CB 85791). - 41. Střední Povltaví: Praha-Modřany (distr. Hlavní město Praha): in Modřanská rokle gorge, ruderal scrub, scattered, $220 \mathrm{~m}$ a.s.1., 5000'16.5"N, 1425'26.6"E, 5952d, FCM 0.364, 2n = 22, ID 132 (18 V 2017 leg. ML, CB 85785). - Zbraslav (distr. Hlavní město Praha): in Břežanské údolí valley ca $300 \mathrm{~m}$ SE of railway station, road edge, rare, $210 \mathrm{~m}$ a.s.1., 4958'10.3"N, 14²4'12.9"E, 6052a, FCM 0.363, ID 131 (18 V 2017 leg. ML, CB 85786). - Hradištko (distr. Praha-západ): in Vltava river valley ca $630 \mathrm{~m}$ ENE of Žižkův vrch hill, Galio-Urticetea at road edge, rare, 210 m a.s.1., 4952'06.7"N, 14²3'38.2"E, 6152a, FCM 0.365, ID 135 (24 V 2017 leg. ML \& PK, CB 85781).

\section{Stellaria pallida}

37l. Českokrumlovské Předšumaví: Český Krumlov (distr. Český Krumlov): ca 130 m W of chapel in Křǐžová street, joint in pavement, rare, $505 \mathrm{~m}$ a.s.1., 4848'27.9"N, 14²19'17.5"E, 7151d, FCM 0.302, ID 98 (4 V 2017 leg. ML, CB 85759). - Nové Spolí (distr. Český Krumlov): near Vltava river ca $550 \mathrm{~m} \mathrm{SW}$ of chapel in village, disturbed grassland in camp by river, rare, $490 \mathrm{~m}$ a.s.1., 48 47'51.7" $\mathrm{N}, 14^{\circ} 18^{\prime} 28.9^{\prime \prime} \mathrm{E}, 7251 \mathrm{~b}, \mathrm{FCM} 0302$, 2n = 22, ID 99 (4 V 2017 leg. ML, CB 85760). - 37p. Novohradské podhůří: Plav (distr. České Budějovice): ca $220 \mathrm{~m} \mathrm{SW}$ of chapel in centre of village, open sandy grassland, abundant, $405 \mathrm{~m}$ a.s.1., $48^{\circ} 54^{\prime} 01.0^{\prime \prime} \mathrm{N}, 14^{\circ} 29^{\prime} 10.6^{\prime \prime} \mathrm{E}, 7052 \mathrm{~d}$, FCM 0.308, ID 95 (4 V 2017 leg. ML, CB 85757). - Nedabyle (distr. České Budějovice): ca 350 m WNW of chapel in centre of village, road ditch, rare, $470 \mathrm{~m}$ a.s.1., 48 55'43.2" $\mathrm{N}, 14^{\circ} 30^{\prime} 43.3^{\prime \prime} \mathrm{E}, 7053 \mathrm{c}, \mathrm{FCM} 0.303$, ID 93 (4 V 2017 leg. ML, CB 85755). - 38. Budějovická pánev: České Budějovice (distr. České Budějovice): SE edge of Stromovka park, grassland, scattered, $390 \mathrm{~m}$ a.s.1., 48 58'07.2"N, 14²7'46.5"E, 7052b, FCM 0.304, ID 101 (5 V 2017 leg. ML, CB 85762). - České Budějovice (distr. České Budějovice): slopes above Mlýnská stoka millrace in Luční street, open grassland below trees, abundant, 390 m a.s.1., 48 57'54.8"N $14^{\circ} 28^{\prime} 55.9^{\prime \prime} \mathrm{E}, 7052 \mathrm{~b}$, FCM 0.302, ID 103 (5 V 2017 leg. ML, CB 85764). - České Budějovice (distr. České Budějovice): in Plavská street, ca $90 \mathrm{~m}$ SW of Velký jez weir, urban grassland, scattered, $390 \mathrm{~m}$ a.s.1., 48 ${ }^{\circ} 57^{\prime} 20.2^{\prime \prime} \mathrm{N}, 1^{\circ} 28^{\prime} 42.5^{\prime \prime} \mathrm{E}, 7052 \mathrm{~b}$, FCM 0.306, 2n = 22, ID 105 (5 V 2017 leg. ML, CB 85766). - České Budějovice (distr. České Budějovice): W end of Jana Kollára street, urban grassland, scattered, 390 m a.s.1., 48 57'19.9"N, 14²27'46.7"E, 7052b, FCM 0.299, ID 106 (5 V 2017 leg. ML, CB 85767). - České Budějovice (distr. České Budějovice): E end of Osiková street in Mladé quarter, urban grassland, scattered, 395 m a.s.1., 48 $57^{\prime} 23.6^{\prime \prime} \mathrm{N}, 1^{\circ} 29^{\prime} 32.4^{\prime \prime E}, 7052 b$, FCM 0.301, ID 92 (4 V 2017 leg. ML, CB 85754). - 39. Třeboňská pánev: Veselí nad Lužnicí (distr. Tábor): in Na Pískách street, urban lawn, scattered, 410 m a.s.1., 49¹1'11.0"N, 14²4'17.6"E, 6854a, FCM 0.303, ID 86 (3 V 2017 leg. ML, CB 85743). - 41. Střední Povltaví: Praha-Modřany (distr. Hlavní město Praha): in Modřanská rokle gorge, gap in plantation of Pinus sylvestris, Larix decidua, Quercus sp., ca 40 individuals, $220 \mathrm{~m}$ a.s.1., 50 $00^{\prime} 13.9^{\prime \prime} \mathrm{N}$, $14^{\circ} 25^{\prime} 16.9^{\prime \prime E}, 5952$ d, FCM 0.297, ID 133b (24 V 2017 leg. ML, CB 85783).

\section{Stellaria ruderalis}

8. Český kras: Sedlec (distr. Beroun): ca $200 \mathrm{~m}$ ENE of chapel in centre of village, road ditch, abundant, $250 \mathrm{~m}$ a.s.1., 49 58'45.1"N, 1408'22.7"E, 6050b, ID 77 (30 IV 2017 leg. ML \& PL, CB 85740). - Sedlec (distr. Beroun): ca $1.1 \mathrm{~km}$ NE of chapel in village, road ditch, rare, $255 \mathrm{~m}$ a.s.1., 49 $59^{\prime} 01.6^{\prime \prime} \mathrm{N}, 1^{\circ} 09^{\prime} 01.0^{\prime \prime} \mathrm{E}, 6050 \mathrm{~b}$, FCM 0.639, ID 121 (12 V 2017 leg. ML, CB 85773). - 37l. Českokrumlovské Předšumaví: Český Krumlov (distr. Český Krumlov): ca $610 \mathrm{~m}$ NNE of St. Vít church, ruderal grassland below trees, abundant, $485 \mathrm{~m}$ a.s.1., 4848'54.9"N, 14²19'08.9"E, 7151d, FCM 0.638, ID 100 (4 V 2017 leg. ML, CB 85761). - Zlatá Koruna (distr. Český Krumlov): near Vltava river ca $230 \mathrm{~m}$ ENE of church in village, forest and meadow edge, abundant, 455 m a.s.1., 48 51'20.4"N, 14²2'25.9"E, 7152a, FCM 0.638, ID 97 (4 V 2017 leg. ML, CB 85758). - 37p. Novohradské podhůří: Plav (distr. České Budějovice): ca $370 \mathrm{~m}$ NE of chapel in centre of village, road edge, large growth, $430 \mathrm{~m}$ a.s.1., 48 54'14.9"N, 14²9'30.3"E, 7052d, FCM 0.641, ID 79 (2 V 2017 leg. ML, CB 85748). - Trocnov (distr. České Budějovice): ca $50 \mathrm{~m}$ ESE of railway stop, road embankment, abundant, 520 m a.s.1., $48^{\circ} 54^{\prime} 09.5^{\prime \prime} \mathrm{N}, 14^{\circ} 35^{\prime} 15.8^{\prime \prime E}, 7053$ d, FCM 0.645, ID 80 (2 V 2017 leg. ML, CB 85749). - Svébohy 
(distr. České Budějovice): ca $320 \mathrm{~m}$ NNE of chapel in village, road edge, abundant, $535 \mathrm{~m}$ a.s.1., 48 ${ }^{\circ} 47^{\prime} 00.4^{\prime \prime} \mathrm{N}$, 1443'25.5"E, 7254a, FCM 0.660, ID 81 (2 V 2017 leg. ML, CB 85751). - 38. Budějovická pánev: Bavorovice (distr. České Budějovice): ca $900 \mathrm{~m} \mathrm{NW}$ of chapel in village, road edge, scattered, $375 \mathrm{~m}$ a.s.1., 4901'51.9" $\mathrm{N}$, 14²5'58.2"E, 6952d, FCM 0.651, 2n = 44, ID 114 (10 V 2017 leg. ML, CB 85775). - České Budějovice (distr. České Budějovice): ca $300 \mathrm{~m} \mathrm{~S}$ of centre of Nový most bridge (over Vltava river), edge of wet, ruderal scrub, rare, 380 m a.s.1., 48 59'24.5"N, 14²7'36.5"E, 7052b, FCM 0.652, ID 107 (10 V 2017 leg. ML, CB 85776). České Budějovice (distr. České Budějovice): along Mlýnská stoka millrace in Březová street, ruderal grassland, abundant, 390 m a.s.1., 48 57'34.9"N, 14²8'50.9"E, 7052b, FCM 0.638, ID 104 (5 V 2017 leg. ML, CB 85765). - 39. Třeboňská pánev: Veselí nad Lužnicí (distr. Tábor): Alešovo nábřeží street, slope above Nežárka river, ruderal grassland, abundant, $410 \mathrm{~m}$ a.s.1., 49¹1'06.9"N, 14²42'12.0"E, 6854a, FCM 0.653, ID 85 (3 V 2017 leg. ML, CB 85742). - Veselí nad Lužnicí (distr. Tábor): Alešovo nábřeží street, slope above Nežárka river, ruderal grassland, abundant, $400 \mathrm{~m}$ a.s.1., 49¹1'05.7"N, 1442'13.3"E, 6854a, FCM 0.648, ID 88 (3 V 2017 leg. ML, CB 85744). - Vlkov (distr. Tábor): ca 50 m NNW of railway stop, ruderal grassland on slopes above railway, several growths, $415 \mathrm{~m}$ a.s.1., $49^{\circ} 08^{\prime} 54.9^{\prime \prime} \mathrm{N}, 14^{\circ} 43^{\prime} 41.5^{\prime \prime} \mathrm{E}, 6854 \mathrm{c}$, FCM 0.642, ID 89 (3 V 2017 leg. ML, CB 85746). - 41. Střední Povltaví: Praha-Modřany (distr. Hlavní město Praha): in Modřanská rokle gorge, gap in plantation of Pinus sylvestris, Larix decidua, Quercus sp., several individuals, 220 m a.s.1., 5000'13.9"N, 14²5'16.9"E, 5952d, FCM 0.652, ID 133a (24 V 2017 leg. ML, CB 85784). Zbraslav (distr. Hlavní město Praha): in Břežanské údolí valley ca $300 \mathrm{~m}$ SE of railway station, road edge, scattered, 210 m a.s.1., 49 58'10.5"N, 14²4'12.6"E, 6052a, FCM 0.648, ID 130 (18 V 2017 leg. ML, CB 85787). Voznice (distr. Příbram): ca $200 \mathrm{~m}$ NE of centre of damp of Velký rybník fish-pond, ruderal grassland, scattered, 380 m a.s.1., 4949'09.6"N, 14¹3'12.5"E, 6151c, FCM 0.651, ID 74 (30 IV 2017 leg. ML \& PL, CB 85737). - Dobříš (distr. Př́ibram): ca $650 \mathrm{~m}$ NE of castle in town, grassland at road edge, scattered, $360 \mathrm{~m}$ a.s.1., 494' 13.3"N, 14¹0'58.9"E, 6251a, FCM 0.644, ID 75 (30 IV 2017 leg. ML \& PL, CB 85738).

Appendix 2. - Other records of Stellaria ruderalis documented by herbarium specimens. Specimens from the Czech Republic are sorted according to the Czech regional-phytogeographical classification system (Skalický 1988) and according to the quadrant numbers of the Central European grid mapping system (Ehrendorfer \& Hamann 1965). Specimens from other countries are sorted according to the quadrant numbers of the Central European grid mapping system. Names of collectors are abbreviated as follows: JV = J. Velebil, ML = M. Lepší, $P L=P$. Lepší, ZK = Z. Kaplan. Accession numbers in the CB herbarium (acronym according to Thiers 2018) and collection numbers in Z. Kaplan's herbarium follow the initials of collectors. Additional information provided by the authors of this paper not present on the original herbarium labels are enclosed in square brackets.

\begin{abstract}
Austria
Hainburg an der Donau (distr. Bruck an der Leitha): ca $180 \mathrm{~m}$ NNE of summit of Schulerbergl hill, ruderal scrub and forest, scattered, $180 \mathrm{~m}$ a.s.1., 4809'09.8"N, 1656'50.1"E, 7867b (8 V 2018 leg. ML \& JV, CB 86008). - Hainburg an der Donau (distr. Bruck an der Leitha): ca 110 m ESE of summit of Königswarte hill, edges of scrub, abundant, $330 \mathrm{~m}$ a.s.1., 48 $06^{\prime} 55.3^{\prime \prime} \mathrm{N}, 1^{\circ} 01^{\prime} 28.5^{\prime \prime} \mathrm{E}, 7868 \mathrm{c}$ (12 V 2018 leg. ML \& JV, CB 86011). - Gumpoldskirchen (distr. Mödling): ca $580 \mathrm{~m} \mathrm{~N}$ of summit of Heberlberg, on forest road, several growths, 320 m a.s.1., 4802'15.4"N, 16²15'22.6"E, 7963d (7 V 2018 leg. ML \& JV, CB 86009). - Hainburg an der Donau (distr. Bruck an der Leitha): ca $210 \mathrm{~m} \mathrm{~W}$ of summit of Steinberg hill, edge of path in forest, scattered, 260 m a.s.1., 4805'43.1"N, 1658'25.2"E, 7967 b (8 V 2018 leg. ML \& JV, CB 86012).
\end{abstract}

\title{
Croatia
}

Istria County, Municipality of Ližnjan: herb vegetation along track between orchards and gardens $1 \mathrm{~km} \mathrm{E}$ of Šišan, 70 m a.s.1., 4451'04.7"N, 1357'36.8"E (9 V 2019 leg. ZK, P. Koutecký \& M. Lučanová 19/15, herb. Kaplan).

\section{Czech Republic}

11a. Všetatské Polabí: Dvorce (u Lysé nad Labem, distr. Nymburk): okraj doubravy u cesty $270 \mathrm{~m}$ VJV od železniční zastávky Lysá nad Labem-Dvorce, 185 m a.s.1., 50¹1'58"N, 1448'22"E, 5754d (15 IV 2007 leg. ZK 07/21, herb. Kaplan). - 16. Znojemsko-brněnská pahorkatina: Dukovany (distr. Třebíč): in Jihlava river valley (right hand-bank) along road to Mohelenský mlýn mill ca $1.6 \mathrm{~km} \mathrm{~N}$ of castle in village, road ditch in forest, scattered, $290 \mathrm{~m}$ a.s.1., 4905'47.7"N, 16²1'52.6"E, 6963a (19 V 2016 leg. ML \& PL, CB 84365). Jamolice (distr. Znojmo): in Templštejn castle ruins, ruderal growths, abundant, $360 \mathrm{~m}$ a.s.1., $49^{\circ} 05^{\prime} 24.9^{\prime \prime} \mathrm{N}$, 16²14'54.2"E, 6963a (22 V 2016 leg. ML \& PL, CB 84348). - 18a. Dyjsko-svratecký úval: Vranovice (distr. 
Brno-venkov): vlhký okraj lesní cesty v lužním lese 0,6 km JJV od obce, $172 \mathrm{~m}$ a.s.1., 4857'22.3"N, 16³6'47.9"E, 7065b (22 IV 2016 leg. ZK 16/1, herb. Kaplan). - Ivaň (distr. Brno-venkov): vlhký okraj lesní cesty v lužním lese $0,3 \mathrm{~km}$ ZJZ od obce, $172 \mathrm{~m}$ a.s.1., 48 55'34.8"N, 16³4'12.6"E, 7065c (22 IV 2016 leg. ZK 16/2, herb. Kaplan). - Hlohovec (distr. Břeclav): břeh náhonu Včelínek vedle soustavy násadových rybníků (výtažníků) mezi rybníky Nesyt a Hlohovecký 0,7 km ZSZ od obce, 170 m a.s.1., 4846'43.3"N, 1645'00.3"E, 7266 b (22 IV 2016 leg. ZK 16/4, herb. Kaplan). - Břeclav (distr. Břeclav): vlhký okraj lesní cesty v Bořím lese 2,8 km Z od železniční stanice Poštorná, 185 m a.s.1., 4845'01.0"N, 16²48'50.0"E, 7266d (31 V 2016 leg. ZK 15/77, herb. Kaplan). - 37j. Blanský les: Krasetín (distr. Český Krumlov): at E edge of village along road to Holubov, ruderal grassland, abundant, $550 \mathrm{~m}$ a.s.1., 48 53'02.7"N, 14²19'11.0"E, 7151b (20 IV 2016 leg. ML \& PL, CB 84264). - Krasetín (distr. Český Krumlov): S edge of village, Sambucus nigra scrub, scattered, $580 \mathrm{~m}$ a.s.1., 48 $52^{\prime} 47.9^{\prime \prime} \mathrm{N}, 1^{\circ} 19^{\prime} 02.6^{\prime \prime E}, 7151 \mathrm{~b}$ (20 IV 2016 leg. ML \& PL, CB 84249). - Krasetín (distr. Český Krumlov): $\mathrm{S}$ edge of village, edge of ruderal scrub, scattered, $585 \mathrm{~m}$ a.s.1., $48^{\circ} 52^{\prime} 48.3^{\prime \prime} \mathrm{N}, 1^{\circ}{ }^{\circ} 19^{\prime} 02.8^{\prime \prime E}, 7151 \mathrm{~b}$ (2 V 2016 leg. ML, CB 84326). - 37k. Křemžské hadce: Mř́č (distr. Český Krumlov): NE edge of village, in disturbed place in grassland, rare, $540 \mathrm{~m}$ a.s.1., 48 54'34.7"N, 14²19'41.8"E, 7051d (2 V 2016 leg. ML, CB 84324). - 371. Českokrumlovské Předšumaví: Český Krumlov (distr. Český Krumlov): U Poráků street, open ruderal grassland, abundant, $490 \mathrm{~m}$ a.s.1., 4848'54.9"N, 14²19'08.8"E, 7151d (2 V 2016 leg. ML, CB 84321). 37n. Kaplické mezihoří: Zubčice (distr. Český Krumlov): along road to Kaplice ca $1 \mathrm{~km}$ SE of center of village, grassy road edge, several individuals, $610 \mathrm{~m}$ a.s.1., 48 47'15.8"N, 14²5'06.6"E, $7252 \mathrm{~b}$ (10 V 2016 leg. ML, CB 84290). - 37p. Novohradské podhůří: Kosov (distr. České Budějovice): along road České Budějovice - Český Krumlov ca $870 \mathrm{~m}$ SSW of centre of village, road ditch, rare, $500 \mathrm{~m}$ a.s.1., $48^{\circ} 52^{\prime} 20.3^{\prime \prime} \mathrm{N}$, 14²4'54.9"E, 7152a (2 V 2016 leg. ML, CB 84327). - 38. Budějovická pánev: České Budějovice (distr. České Budějovice): in floodplain of Vltava river (left-hand bank) near Nový most bridge, edge of scrub, scattered, 380 m a.s.1., 4859'25.0"N, 14²7'35.2"E, 7052b (13 V 2016 leg. ML, CB 84334). - České Budějovice (distr. České Budějovice): left-hand bank of millrace near Velký jez weir on Malše river, disturbed grassland, abundant, $390 \mathrm{~m}$ a.s.1., 4857'24.4"N, 14²8'48.6"E, 7052b (27 IV 2016 leg. ML, CB 84262). - České Budějovice (distr. České Budějovice): near Křižíkova street, railway, rarely, $390 \mathrm{~m}$ a.s.1., 48 57'37.9"N, 142ㅇ0‥3"E, 7052b (27 IV 2016 leg. ML, CB 84261). - České Budějovice (distr. České Budějovice): near weir in Rožnov quarter, left-hand bank of Vltava river, grassy river bank, rare, $390 \mathrm{~m}$ a.s.1., 48 ${ }^{\circ} 57^{\prime} 01.4^{\prime \prime} \mathrm{N}$, 14²7'47.7"E, 7052b (26 IV 2016 leg. ML, CB 84247). - České Budějovice (distr. České Budějovice): near weir on Vltava river in Rožnov quarter, left-hand bank of millrace, disturbed place at river bank, rare, $390 \mathrm{~m}$ a.s.l., 485' $59.5^{\prime \prime} \mathrm{N}, 1^{\circ} 27^{\prime} 45.7 " \mathrm{E}, 7052 \mathrm{~d}$ (26 IV 2016 leg. ML, CB 84248). - 39. Třeboňská pánev: Frahelž (distr. Jindřichův Hradec): near train stop, disturbed grassland above railway, scattered, $420 \mathrm{~m}$ a.s.1., 4907'06.2"N, 1444'11.3"E, 6854c (1 V 2016 leg. ML, CB 84322). Lužnice (distr. Jindřichův Hradec): bylinný porost pod lípou u staré cesty k železniční zastávce poblíž JJZ okraje obce, 431 m a.s.1., 4903'15.9"N, 1445'00.5"E, 6954b (16 IV 2017 leg. ZK 17/7, herb. Kaplan). - Chlum u Třeboně (distr. Jindřichův Hradec): ca 1.2 km SSE of centre of dam of Hejtman pond, road edge, abundant, $460 \mathrm{~m}$ a.s.1., 48 ${ }^{\circ} 57^{\prime} 00.1^{\prime \prime} \mathrm{N}, 1^{\circ}{ }^{\circ} 56^{\prime} 21.2^{\prime \prime} \mathrm{E}, 7055 \mathrm{~b}(27 \mathrm{~V} 2016$ leg. ML \& PL, CB 84188). - Vlkov (distr. Tábor): near train stop, edge of ruderal scrub, scattered, $420 \mathrm{~m}$ a.s.1., 4908'53.9"N, 14²3'41.4"E, 6854c (1 V 2016 leg. ML, CB 84323). - 40a. Písecko-hlubocký hřeben: Hluboká nad Vltavou (distr. České Budějovice): in park of Hluboká nad Vltavou castle, undergrowth of open forest, rare, $420 \mathrm{~m}$ a.s.1., 4903'19.8"N, 14²5'57.1"E, 6952b (7 V 2016 leg. ML, CB 84302). - 41. Stř̌ední Povltaví: Vrané nad Vltavou (distr. Praha-západ): okraj paseky v lese u silničky do Zvole, 0,8 km VJV od hlavní budovy železniční stanice, 325 m a.s.1., 4956'10.2"N, 14²3'32.4"E, 6052c (8 V 2010 leg. ZK 10/54, herb. Kaplan). - Vrané nad Vltavou (distr. Praha-západ): humózní hlinitý svah nad cestou u křižovatky ulic V Dolích a Ke Zvoli při dolním okraji údolí Zvolského potoka v S části obce, $180 \mathrm{~m}$ VJV od železniční stanice Vrané nad Vltavou, 215 m a.s.1., 4956'16.9"N, 14²3'00.4"E, 6052c (2 V 2015 leg. ZK 15/26, herb. Kaplan). Jarov (distr. Praha-západ): bylinný podrost v lemu listnatého lesíka u železniční zastávky při J okraji vsi, 205 m a.s.1., 49 56'50.6"N, 14²23'47.9"E, 6052c (2 V 2015 leg. ZK 15/28, herb. Kaplan). - Dobronice u Bechyně (distr. Tábor): bylinný porost podél lesní pěšinky na svahu nad pravým břehem Lužnice $0,5 \mathrm{~km} \mathrm{SV}$ od obce, 390 m a.s.1., 49²0'47.9"N, 14³0'15.0"E, 6653c (30 V 2017 leg. ZK 17/70, herb. Kaplan). Černýšovice (distr. Tábor): bylinný podrost při okraji silnice vedoucí lesem u JV okraje obce, $430 \mathrm{~m}$ a.s.l., 49¹9'19.7"N, 14³1'26.9"E, 6653c (1 VI 2017 leg. ZK 17/72, herb. Kaplan). - Neznašov (distr. České Budějovice): ca $1.2 \mathrm{~km}$ ESE of the centre of village, road margin in forest, scattered, $370 \mathrm{~m}$ a.s.l., 4913'40.0"N, 14²3'38.8"E, 6752c (31 V 2016 leg. ML, CB 84313). - 64a. Průhonická plošina: Ř́ícany (distr. Praha-východ): okraj lesíku nad pravým břehem Říčanského potoka u silnice u ZSZ okraje obce, 0,7 km SSZ od Masarykova náměstí, 320 m a.s.1., 4959'52.1"N, 14³9'03.2"E, 6053b (10 V 2015 leg. ZK 15/31, herb. Kaplan). 


\section{Greece}

Region (periphery) of Thessaly (Thessalía), Tríkala Pref.: wood on river bank $0.5 \mathrm{~km}$ NW of Theópetra, $170 \mathrm{~m}$ a.s.1., 3940'46.7"N, 2140'35.4"E, 6396c (2 V 2017 leg. ZK, J. Prančl \& P. Koutecký 17/20, herb. Kaplan).

\section{Hungary}

Tatabánya (distr. Tatabánya): ca 3.9 km N of centre of village Környe, road ditch, 180 m a.s.1., 47³4'54.0 "N, $18^{\circ} 19^{\prime} 22.3 " \mathrm{H}, 8475 b$ ( 7 V 2019 ML \& JV, CB 86099).

\section{Italy}

Region of Veneto, Metropolitan City of Venice: disturbed roadside grassland at motorway exit $\mathrm{N}$ of Mestre, $1 \mathrm{~m}$ a.s.1., [4530'58"N, 12¹4'39"E, 0439c] (10 IV 1993 leg. ZK 93/4, herb. Kaplan). - Region of Toscana, Province of Siena: disturbed roadside grassland in Localitŕ Toppo Basso $3.9 \mathrm{~km} \mathrm{NE}$ of Sarteano, $330 \mathrm{~m}$ a.s.1., 4301'37.9"N, 1153'39.1"E, [2937c] (16 IV 2018 leg. ZK, P. Koutecký \& J. Hanzlíčková 18/2, herb. Kaplan). - Region of Toscana, Province of Siena: disturbed grassland on embankment along Torrente Gragnano channel between fields $3.4 \mathrm{~km}$ NNW of Chiusi, $254 \mathrm{~m}$ a.s.1., 4302'50.5"N, 11 $56^{\prime} 09.4^{\prime \prime E}$, [2937d] (16 IV 2018 leg. ZK, P. Koutecký \& J. Hanzlíčková 18/3, herb. Kaplan). - Region of Sardegna (Sardinia), Province of Sud Sardegna: herb vegetation along track under bridge over Rio sa Picocca (river) $0.5 \mathrm{~km}$ WSW of San Priamo, $5 \mathrm{~m}$ a.s.1., 39²1'17.4"N, 09³3'14.2"E, [6623c] (22 IV 2018 leg. ZK, P. Koutecký \& J. Hanzlíčková 18/14, herb. Kaplan). - Region of Sardegna (Sardinia), Province of Nuoro: herb understory of broad-leaved forest at parking place near Su Golognone natural monument 7 km E-ENE of Oliena, $110 \mathrm{~m}$ a.s.1., 40¹7'19.9"N, 09²9'38.8"E, [5722d] (24 IV 2018 leg. ZK, P. Koutecký \& J. Hanzlíčková 18/19, herb. Kaplan).

\section{Serbia}

Paraćin (distr. Pomoravlje): ruderal site at petrol station on motorway A1 1.5 km NNW of Paraćin, $132 \mathrm{~m}$ a.s.1., 435'ㄷ.9"N, 2124'01.3"E, [2194c] (30 IV 2017 leg. ZK, P. Koutecký \& J. Prančl 17/10, herb. Kaplan).

\section{Slovakia}

Kuchyňa (distr. Malacky): ca 680 m SW of summit of Bučková, edge of forest road, tens of individuals, $345 \mathrm{~m}$ a.s.1., 48 $25^{\prime} 18.7^{\prime \prime} \mathrm{N}, 17^{\circ} 11^{\prime} 36.0^{\prime \prime E}, 7569 \mathrm{c}(10 \mathrm{~V} 2018$ leg. ML \& JV, CB 86013). - Vysoká pri Morave (distr. Malacky): okraj lužního lesa 1,5 km ZSZ od obce, 145 m a.s.1., [48²0'17"N, 1653'20"E, 7667c] (10 V 1994 leg. ZK 94/54, herb. Kaplan). - Děvín (distr. Bratislava): ca 2.1 km NNE of Děvín castle, edge of forest road, abundant, 190 m a.s.1., 48¹1'34.9"N, 1658'46.1"E, 7867b (9 V 2018 leg. ML \& JV, CB 86010).

\section{Slovenia}

Coastal-Karst Statistical Region (Obalno-kraška regija), Municipality of Koper: saline sands near sea coast at SW edge of Ankaran, 5 m a.s.1., [45³4'33"N, 1344'06"E, 0448c] (16 IV 1996 leg. ZK, J. Štěpánek \& J. Štěpánková 96/4, herb. Kaplan). 